\title{
A comparison of vascular vegetation and protozoan communities in some freshwater wetlands of Northern Lower Michigan
}

\author{
M. S. Henebry, J. Cairns, Jr., C. R. Schwintzer* \& W. H. Yongue, Jr. \\ University Center for Environmental Studies, Virginia Polytechnic Institute and State University, \\ Blacksburg, VA 2406I, U.S.A. and The University of Michigan Biological Station, Pellston, MI 49769, USA
}

* Present address: Harvard University, Harvard Forest, Petersham, MA 01366, USA

Keywords: wetland ecology, protozoan ecology, bogecology, protozoan colonization

\begin{abstract}
Vascular vegetation and protozoan communities were sampled in seven wetland sites - two bogs, two fens, two marshes, and one 'swamp' - in summer 1977. Two similarity indices were used to compare vascular vegetation and Protozoa from each site with all the other sites. Bog sites were the most distinct from other wetland types with respect to chemical and physical characteristics, dominant vascular vegetation, and protozoan species composition. The 'swamp' site had the highest similarity to all other sites with respect to both dominant vascular vegetation and protozoan species. Protozoan communities from different wetland types were much more similar than dominant vascular species; however, the pattern of similarity between wetland sites was very similar for both groups (Pearson product-moment correlation coefficient $=0.76$ ).

Protozoan communities were also compared with those from several nearby lakes with respect to colonization rate onto polyurethane foam artificial substrates. The structure and dynamics of protozoan communities of wetlands were broadly different from those of other freshwaters, and somewhat unique to the other wetland types. Evidence for a high degree of eutrophy in certain bog lakes is presented.
\end{abstract}

\section{Introduction}

Marshes, bogs, fens, and swamps - the four major wetland types - attract considerable attention as man continues to modify and develop these fragile ecosystems. While some physiochemical information and data on higher plants are available for each of these wetland types, they have received less attention than they deserve from hydrobiologists and microbiologists. Microbial investigators have neglected these ecosystems largely because the mosaic of microhabitats in each of the vegetation types of the four wetland formations present difficult sampling problems. However, the aquatic component of wetlands is important for the maintenance of water quality and ecological integrity of adjacent lakes and rivers (National Wetlands Technical Council 1979). This study will compare and contrast protozoan (including phytoflagellate algae) community structure with that of vascular plant vegetation in three of the four major freshwater wetland types. Protozoan community structure and the dynamics of the colonization process in protozoan communities of wetland sites will be compared to those of freshwater ecosystems generally, particularly of nearby lakes.

Environmental conditions encountered by Protozoa in each wetland type are influenced by vegetation and water levels at the site. The vegetation helps to determine the microclimate in which Protozoa live, including temperature and light regimes. Vegetational litter composition (nutrient content, tannins, etc.) and the presence or absence of species capable of symbiotic nitrogen fixation such as Alnus rugosa and Myrica gale help to determine chemical regimes. 
A limited body of information is available about the vegetation, water characteristics, and water levels in northern Michigan wetlands. Early studies by Gates (1942) and his students provide qualitative descriptions of wetland vegetation and general descriptions of wetland sites. Later studies provide quantitative information on vegetation and some water characteristics in a limited number of bogs (Vitt \& Slack 1975; Schwintzer 1978a, 1979) and fens (Schwintzer 1978b). Water levels have also been described at one bog (Schwintzer 1978b, 1979).

Microbes (algae, Protozoa, and bacteria) of wetlands may contribute substantially to the annual primary productivity and overall metabolism of the aquatic component of these ecosystems. Bog vegetation in particular has been characterized as having very slow rates of growth and slow rates of decomposition (Wetzel 1975), but bogs may have very high standing crops of plankton (Gannon \& Paddock 1974; Bricker \& Gannon 1976).

Bog lakes in Cheboygan County, Michigan have been the focus of several limnological investigations in the past (Jewel \& Brown 1929; Gorham 1931; Welch 1936; Gates 1942). Of these, only Welch (1936) has investigated the Protozoa of a bog lake. Many species of Protozoa and phytoflagellate algae have been identified as 'acidophilous' or as living primarily in the Sphagnum spp. mat of acid lakes or bogs (Kahl 1930-1935; Smith 1950; Kudo 1966; and others). However, no general survey of the Protozoa of all four major types of wetlands has been attempted.

This study was designed to examine vegetation, water levels, water chemistry, and Protozoa in the major wetland types to determine: (1) similarities and differences among wetland types, and (2) extent of covariation between vegetation, Protozoa, and water characteristics. We also wanted to determine if the Protozoa of wetland freshwaters are part of a larger freshwater continuum or whether they are unique and ecologically isolated from Protozoa of nearby lakes in northern Michigan. We wanted to see if there were a core species pool for all freshwaters in the area (preliminary evidence for this concept is in Yongue et al. 1973) with a few unique species in certain wetland habitats, or if there were truly ecologically isolated assemblages of Protozoa for particular wetland types. Also, we wanted to ascertain if the dynamics of protozoan communities in wetlands were different from those observed in other freshwater habitats (Plafkin et al. in press).

The use of polyurethane foam unit (PFU) artificial substrates permitted uniform replicate samples to be collected from the diverse habitats in the various types of wetlands. The dynamics of protozoan communities have been successfully investigated in a variety of habitats using PFU artificial substrates (Cairns et al. 1973; Cairns \& Yongue 1974). Henebry \& Cairns (1980) discuss the advantages of using protozoan communities collected on artificial substrates in studies of community ecology.

\section{Study area}

\section{Characteristics of the area}

The wetlands included in this study are located in Emmet and Cheboygan counties in northern lower Michigan (Fig. 1). Wetlands as identified on US Geological Survey topographic maps occupy approximately $9 \%\left(109 \mathrm{~km}^{2}\right)$ and $15 \%\left(308 \mathrm{~km}^{2}\right)$ of the land areas of Emmet and Cheboygan counties, respectively. The region includes excellent examples of each of the four major wetland types: marsh, bog, fen, and swamp, as defined by Jeglum et al. (1974) for Ontario. This classification scheme is used in this paper and is based primarily on vegetation but also reflects chemical characteristics of soil as shown by Stanek \& Jeglum (1977). They found bog, fen-marsh, and swamp clearly distinguishable on the basis of concentrations of five macronutrients in peats from the Northern Clay Section of Ontario.

Northern lower Michigan is in the Northern Hardwoods Forest section of the Laurentian Mixed Forest (Bailey 1976). The bedrock consists of dolomites and limestones, but outcrops are rare and most of the surface is covered by glacial deposits (Dorr \& Eschman 1970; Alfred et al. 1973).

The region has a warm continental climate (Bailey 1976) with wet and dry periods of up to several years in length which result in fluctuating water tables. Periods of high water occur at intervals of approximately ten years in Lake Michigan-Huron (US Dept. of Commerce, NOAA 
1971) and in the Indian River Watershed, which includes a portion of the study area and is subject to similar meteorological conditions (US Dept.of Interior, Geological Survey 1961 -1976; Schwintzer 1978a). During the summer of 1977 , water levels were low throughout the region and unusually low in some wetlands. Mid-July water levels in Bryant's Bog were $30 \mathrm{~cm}$ lower than at any time since measurements began in 1972 (Schwintzer 1979). Similar observations were made in Inverness Mud Lake Bog. Additional information about the area is given in Schwintzer (1978b).

\section{Individual sites sampled}

Seven wetlands were sampled in summer of 1977. These are shown in Fig. 1 and listed in Table 1 with wetland type, exact geographical location, and references to other studies dealing with the site. The following criteria were used in site selection: (a) presence of vegetation typical of one of the major wetland types, (b) presence of standing water intimately associated with the wetland, and (c) ease of access from the University of Michigan Biological Station to minimize the time between sample collection and analysis.

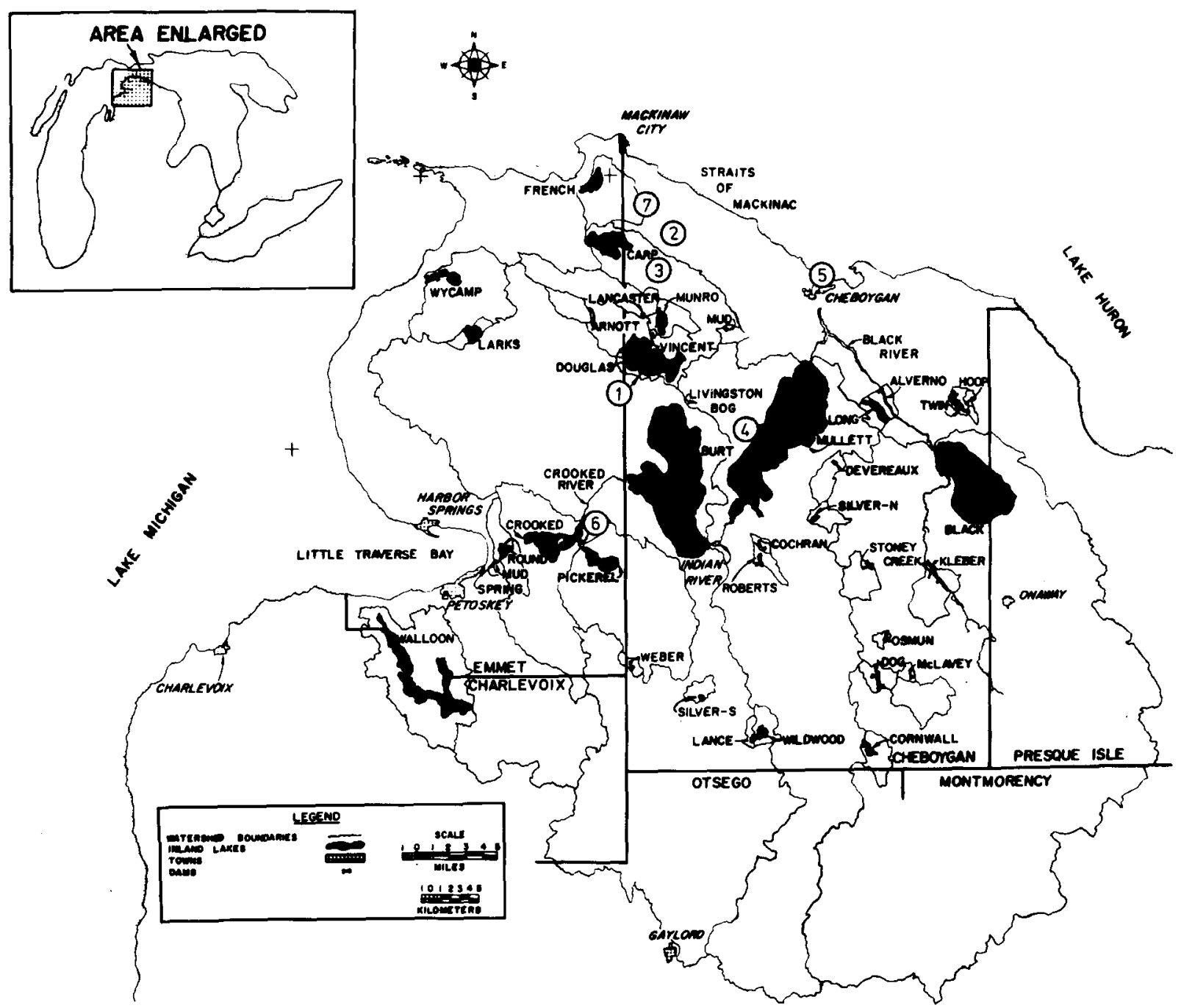

Fig. 1. Map of northern lower Michigan showing locations of wetlands sampled in summer 1977. (1) Bryant's Bog, (2) Penny Lake Bog, (3) Mud Lake Fen, (4) Mullett Creek Fen, (5) Cheboygan Marsh, (6) Minnehaha Marsh, (7) Hebron 'Swamp.' 
Bog, fen, and marsh sites were readily identified to meet these criteria. Difficulty was experienced in finding suitable swamp sites because low water levels during summer of 1977 resulted in absence of standing water in depressions which often contain standing water during much of the summer. The individual sites are described below.

Bryant's Bog is a small kettle-hole bog consisting of two concentric zones: a free floating and a grounded mat surrounding a central pool. Vegetation samples were taken on the free floating mat. The microbial communities were sampled in the northwest section of the bog pool.

Penny Lake Bog is an open bog surrounding a small bog lake located at the eastern edge of Dingman Bog, an extensive bog in the upper reaches of the Mill Creek watershed. Vegetation samples were taken on the east, north, and west sides of Penny Lake. The microbial communities were sampled near the northeastern edge of the bog lake.

Mullet Creek Fen is an open fen extending along both sides of Mullet Creek from its banks to conifer swamps on slightly higher ground. The banks of the slowly flowing creek are irregular in shape and form several small bays of open water surrounded by fen vegetation on three sides. Vegetation samples were taken on both sides of the creek. The microbial communities were sampled in one of the bays along the southwest side of the creek near the center of the fen.

Hebron Mud Lake Fen is an open fen extending along the northeastern and eastern shores of Hebron Mud Lake from the edge of the lake to conifer swamp on slightly higher ground. The shore of the lake is irregular, forming several small bays of open water surrounded by fen vegetation on three sides. Vegetation samples were taken on the northeast and east sides of the lake. The microbial communities were sampled in a bay on the northeast side of the lake.

Hebron 'Swamp' is a portion of an extensive, conifer covered peatland complex extending along the Carp Lake drainage from Inverness Mud Lake to Hebron Mud Lake. A power line and associated gravel access road cross the peatland at right angles to Mud Creek between the Cheboygan-Levering Road and Interstate 75 . The study site is a strip $20 \mathrm{~m}$ wide and $180 \mathrm{~m}$ long, centered on the area with the deepest standing water underneath the power line on the upstream side of the access road. The site has been highly disturbed and water has been impounded by the access road and also Interstate 75 during high water. In addition, much of the woody vegetation has been cleared or destroyed with herbicide. The area is covered by water-filled depressions interspersed with small hummocks. Vegetation samples were taken through-

Table 1. Wetland type, location, and literature references for seven wetland sites in Cheboygan and Emmet counties in northern lower Michigan.

\begin{tabular}{|c|c|c|c|}
\hline Type & Site & Township, range, section & Literature references \\
\hline \multirow[t]{2}{*}{ Bog } & Bryant's Bog & T37N, R3W, Sec 29 & $\begin{array}{l}\text { Schwintzer \& Williams } \\
\text { (1974) reviews numerous } \\
\text { earlier studies } \\
\text { Schwintzer }(1978 \mathrm{a}, 1979)\end{array}$ \\
\hline & Penny Lake & T38N, R3W, Sec 15 & $\begin{array}{l}\text { Jewell \& Brown (1929), } \\
\quad \text { Gates (1942) }\end{array}$ \\
\hline \multirow[t]{2}{*}{ Fen } & Mullet Creek & T36N, R2W, Sec 17 & $\begin{array}{l}\text { Gates (1942); Mullet Creek } \\
\text { is 'Nigger Creek' } \\
\text { (Schwintzer 1978b) }\end{array}$ \\
\hline & Hebron Mud Lake & T38N, R3W, Sec 2l & $\begin{array}{l}\text { Gates (1942); Hebron Mud } \\
\text { Lake Fen is 'Blanchard } \\
\text { Bog' (Schwintzer 1978b) }\end{array}$ \\
\hline Swamp & Hebron 'Swamp' & T38N, R3W, Sec 36 & $\begin{array}{l}\text { Gates (1942); Hebron } \\
\text { 'Swamp' is part of } \\
\text { 'Cheboygan-Cecil Bog' }\end{array}$ \\
\hline Marsh & $\begin{array}{l}\text { Cheboygan Marsh } \\
\text { Minnehaha Creek }\end{array}$ & $\begin{array}{l}\text { T38N, RIW, Sec } 29 \\
\text { T35N, R4W, Sec } 29\end{array}$ & \\
\hline
\end{tabular}


out the strip, and microbial communities were sampled in a depression at the center of the strip.

Cheboygan Marsh is a lakeside deep marsh extending eastward and westward along the shore of Lake Huron from the Mouth of the Cheboygan River. The west marsh has been filled along the Cheboygan River, reducing its size and straightening its eastern edge. Vegetation samples were taken in the west marsh, and microbial communities were sampled near the midpoint of the eastern edge of the west marsh.

Minnehaha Marsh is a deep marsh at the downstream end of a wetland complex extending along the lower end of Minnehaha Creek to Channel Road. It is divided into two interconnected lobes by low conifer covered islands. Vegetation samples were taken in both lobes of the marsh, and microbial communities were sampled in the portion of marsh adjacent to the northeast side of the creek near Channel Road.

\section{Materials and methods}

\section{Field methods: vegetation and water levels}

The vegetation was sampled with nested circular plots. Ground layer species, including low shrubs and bryophytes, were sampled with $1 \mathrm{~m}^{2}$ plots. Bryophytes were divided into two groups, 'Sphagnum spp.' and 'other bryophytes'. Tall shrubs (regardless of d.b.h.) and seedling trees (under $2.5 \mathrm{~cm} \mathrm{d.b.h.)} \mathrm{were} \mathrm{sampled} \mathrm{with} 16 \mathrm{~m}^{2}$ plots. Presence and a visual estimate of percent cover were recorded for each vascular species and bryophyte group. Trees (over $2.5 \mathrm{~cm} \mathrm{d.b.h.)} \mathrm{were}$ sampled in $100 \mathrm{~m}^{2}$ plots. Presence, number of individuals, and d.b.h. were recorded for each tree species.

Thirty or forty sample plots were taken at each wetland site in groups of ten. The groups were widely distributed within the area occupied by a given wetland type. Each group was located in a 60 $\times 60 \mathrm{~m}$ area within individual plots were located randomly.

The Hebron 'Swamp' site was divided into three contiguous $60 \times 20 \mathrm{~m}$ strips, and ten plots were randomly located in each strip. In Bryant's Bog, vegetation samples were taken in 15 random plots which had been located in an earlier study
(Schwintzer \& Williams 1974). Nomenclature for the vascular plants follows Voss (1972) for the gymnosperms and monocots, and Fernald (1950) for all others. Cattail (Typha latifolia) includes some hybrids between $T$. latifolia and $T$. angustifolia.

Water levels were measured in the vegetation sample plots in shallow wells dug in the centers of the plots. The wells were allowed to equilibrate, and water level was measured as the distance from the peat surface to the water. At points where the water table was above the surface, water depth was measured from firm substrate to the water surface.

\section{Data analysis: vegetation}

Percent frequencies, mean percent cover, and importance values (I.V.) were calculated for ground layer species, tall shrub species, and bryophyte groups. Importance values were calculated for vascular plants as the sum of the relative frequency and the relative cover of each species using data for vascular plants only. Importance values for sedge (Carex spp.) and twig-rush (Cladium mariscoides) at the two fen sites were calculated using estimated values of mean cover obtained as described by Schwintzer (1978b).

Coefficients of similarity between stands (Curtis 1959) were calculated for the vascular ground layer vegetation using the formula:

$$
c=[2 w /(a+b)]
$$

where $c$ is the coefficient of similarity, $w$ is the sum of the lower of the two I.V. for species shared by the two sites being compared, and $a$ and $b$ are the sum of all I.V. for communities $\mathrm{A}$ and $\mathrm{B}$.

Field methods: Protozoa samples and water chemistry

Thirty-five $74 \times 64 \times 25 \mathrm{~mm}$ PFU artificial substrates were placed in each of the wetland sites in Table 1 in summer of 1977. PFUs were also anchored in Douglas Lake, Michigan, a mesotrophic lake near the wetland sites. The method of anchoring subtrates was slightly modified from that of Yongue et al. (1973) to allow the PFUs to be interspersed with the emergent vegetation found at each site. Groups of five PFUs were tied to anchors 
(rock-filled plastic bags) which were placed so that each PFU floated just below the water surface and close to or touching emergent vegetation typical of the wetland site.

Four replicate PFUs were collected from each site on days $1,3,6,15$, and 21 after placement. PFUs were also collected at Hebron 'Swamp' on days 28 and 49. All PFU substrates were placed in clean $500 \mathrm{ml}$ glass screw-capped jars completely filled with water from the site and were returned immediately (usually within one hour) to the University of Michigan Biological Station.

Each time PFUs were collected, air and water temperatures were measured with a field thermometer; and dissolved oxygen, $\mathrm{pH}$, and total hardness were measured at the site with a Hach Kit Model DR/EL. Samples were collected for analysis of cations ( $\mathrm{Ca}, \mathrm{Mg}, \mathrm{Na}$, and $\mathrm{Fe}$ ) and heavy metals by filling a 1-1 plastic cubitainer with water from each site. Each water sample was fixed with five drops of concentrated nitric acid and shipped to the water chemistry laboratory at Virginia Polytechnic Institute and State University (VPI \& SU) within several days of collection.

\section{Laboratory methods: Protozoa samples and water chemistry}

Protozoans were harvested by fully squeezing the contents from each of four PFUs (approximately $110 \mathrm{ml}$ of fluid) into separate $500 \mathrm{ml}$ wide-mouth glass jars. After allowing the samples to settle for about half an hour, a glass pipette was used to take subsamples from the miniscus and from the debris which collected in the bottom of each jar. Four wet mount slides were prepared from the contents of the pipette, and the area under a $22 \times 22 \mathrm{~mm}$ coverslip was thoroughly and systematically examined for Protozoa. Protozoa were identified (generally to species) under $100 \mathrm{X}$ and $430 \mathrm{X}$ of a compound microscope using standard taxonomic keys (e.g., Kahl 1930-1935; Pascher 1913-1927; Kudo 1966; Jahn \& Jahn 1949). Each species was assigned an abundance rank according to the following method:

\footnotetext{
Individuals/slide

$1-2$

$3-10$

$11-25$

$26-100$

$>100$
}

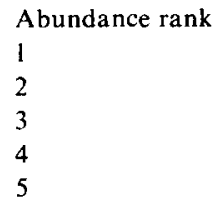

Examination of all samples collected on a particular day was usually completed within $12 \mathrm{~h}$.

All determinations of $\mathrm{Ca}, \mathrm{Mg}, \mathrm{Na}, \mathrm{Fe}$, and heavy metals were performed on a Perkin-Elmer atomic absorption spectrophotometer (US Environmental Protection Agency [USEPA] 1974).

\section{Data analysis: Protozoa}

To determine if the process of species accumulation on PFU artificial substrates could be adequately described by the MacArthur-Wilson noninteractive colonization model, $\mathrm{S}(\mathrm{t})=$ Seq $\left(1-\mathrm{e}^{-\mathrm{GT}}\right)$ with equilibrium species numbers $\widehat{S e q}$ and constant $G$ related to transition time, nonlinear regression procedures with Marquardt methods of estimation (Barr et al. 1976) were used to fit the model to data. Lack of fit tests were then used to test for any significant lack of fit (Cairns et al. 1979).

The similarity of protozoan species content in each pair of wetland sites (and Douglas Lake) was compared using the quotient of similarity (QS) developed by Sorensen (1948) for plant communities. The calculation of $\mathrm{QS}=[2 \mathrm{C} / \mathrm{A}+\mathrm{B}] \times 100$, where $\mathrm{A}=$ the number of species in one assemblage (population, community, etc.), $\mathrm{B}=$ the number of species in another assemblage, and $\mathrm{C}=$ the number of cases in which a species occurs in both populations, results in a value equal to the percentage similarity between two populations in proportion to the similarity that is theoretically possible.

\section{Results}

\section{Vegetation: composition}

Vegetation of the two bog sites consisted of tree, tall-shrub, and ground layers. The tree layer was moderately developed at Bryant's Bog and very sparsely developed at Penny Lake Bog. The tree layer in Bryant's Bog has been described quantitatively (Schwintzer 1978a) and consists of these species in order of decreasing frequency: white pine (Pinus strobus), tamarack (Larix laricina), and black spruce (Picea mariana). In Penny Lake Bog, the tree layer consisted of six species with black spruce, white pine, and tamarack being the most frequent. The tall-shrub layer was 
poorly developed at both sites. It consisted primarily of widely scattered individuals of bog holly (Nemopanthus mucronata) and wild raisin (Viburnum cassinoides) in Bryant's Bog and bog birch (Betula pumila) in Penny Lake Bog.

The ground layer was the most developed layer in both bogs (Table 2). Leatherleaf (Chamaedaphne ('alyculata) was the dominant vascular plant at both Bryant's Bog and Penny Lake Bog with I.V. of 64 and 98, respectively. Sphagnum spp. was also dominant in the two bogs with mean cover exceeding that of leatherleaf in Bryant's Bog and second only to that of leatherleaf in Penny Lake Bog.

The vegetation of the remaining sites consisted entirely of a ground layer (Table 3,4). In both fens, sweet gale (Myrica gale) and hairy-fruited sedge (Carex lasiocarpa) were among the three most dominant vascular plants. Sphagnum spp. was absent, but the 'other bryophytes' group was well developed with mean cover of $15 \%$ and $51 \%$ at Mud Lake Fen and Mullet Creek Fen, respectively.

The two marshes did not have a dominant species in common. Cattail ( $T$ ypha latifolia, I.V. $=84$ ) and hard-stem-bulrush (Scirpus acutus, I.V. = 54) were the leading dominants at Cheboygan Marsh and Minnehaha Marsh, respectively. Bryophytes had only low cover at both sites.

In Hebron 'Swamp', duckweed (Lemna minor, I.V. = 39) was the leading dominant with leatherleaf (I.V. $=32)$ and cattail $(I . V .=27)$ codominant. As in the marshes, bryophytes had only low cover.

Vegetation: coefficients of similarity and total cover

Vascular vegetation at the seven wetland sites was compared by means of coefficients of similarity (c; Table 5). These coefficients reflect species composition, distribution of species within the stand, and their mean cover. The two bogs were similar to each other $(c=0.46)$ and were dissimilar to the fens and marshes $(c \leqslant 0.05)$. The two fens were also similar to each other $(c=0.50)$ and were dissimilar to the bogs $(c \leqslant 0.05)$ and Cheboygan

Table 2. Frequency, cover, and importance value (I.V.) of selected plants and other characteristics of the ground layer vegetation of two bog sites in northern lower Michigan. All vascular plants with I.V. $\geqslant 5$ at one or both sites are included.

\begin{tabular}{|c|c|c|c|c|c|c|}
\hline \multirow[t]{2}{*}{ Species } & \multicolumn{3}{|c|}{ Bryant's Bog } & \multicolumn{3}{|c|}{ Penny Lake Bog } \\
\hline & $\begin{array}{r}\text { freq. } \\
\%\end{array}$ & $\begin{array}{l}\% \text { cover } \\
\mathrm{m} \pm \text { s.d. }\end{array}$ & I. $V^{\mathrm{a}}$ & $\begin{array}{r}\text { freq. } \\
\%\end{array}$ & $\begin{array}{c}\% \text { cover } \\
\mathrm{m} \pm \text { s.d. }\end{array}$ & I.V. \\
\hline Carex oligosperma $a^{b}$ & & & & 67 & $9 \pm 13$ & 39 \\
\hline C. trisperma $a^{\mathrm{b}}$ & 78 & $8 \pm 13$ & 30 & & & \\
\hline Chamaedaphne calyculata & 87 & $25 \pm 17$ & 64 & 67 & $49 \pm 25$ & 98 \\
\hline Eriophorum spissum ${ }^{\mathrm{b}}$ & & & & 27 & $2 \pm 7$ & 15 \\
\hline Gaylussacia baccata & 53 & $3 \pm 7$ & 17 & & & \\
\hline Kalmia polifolia & 33 & $<1$ & 7 & 20 & $2 \pm 5$ & 10 \\
\hline Lycopus uniflorus & 13 & $1 \pm 5$ & 6 & & & \\
\hline Picea mariana & 27 & $3 \pm 10$ & 11 & 3 & $<1$ & 1 \\
\hline Smilacina trifolid & 53 & $10 \pm 12$ & 30 & & & \\
\hline Vaccinium angustifolium ${ }^{\mathrm{b}}$ & 47 & $1 \pm 1$ & 10 & 13 & $3 \pm 9$ & 9 \\
\hline V. myrtilloides ${ }^{\mathrm{b}}$ & 47 & $<1$ & 10 & 10 & $3 \pm 11$ & 8 \\
\hline Sphagnum spp. ${ }^{b}$ & 100 & $90 \pm 17$ & - & 90 & $28 \pm 25$ & - \\
\hline Other bryophytes & 20 & $<1$ & - & 80 & $9 \pm 11$ & - \\
\hline Total no. of vascular plants & & 17 & & & 15 & \\
\hline No. of vascular plants with & & & & & & \\
\hline frequency $\geqslant 10 \%$ & & 10 & & & 6 & \\
\hline Total cover of all vascular plants & & $53 \%$ & & & $69 \%$ & \\
\hline Total cover of all bryophytes & & $91 \%$ & & & $37 \%$ & \\
\hline
\end{tabular}

a The importance value is the sum of the relative frequency and the relative mean cover.

b Not present at fen and marsh sites studied. 
Table 3. Frequency, cover, and importance value (I.V.) of selected plants and other characteristics of the ground layer vegetation of two fen sites in northern lower Michigan.

All vascular plants with $I . V$. $\geqslant 5$ at one or both sites are included.

\begin{tabular}{|c|c|c|c|c|c|c|}
\hline \multirow[t]{2}{*}{ Species } & \multicolumn{3}{|c|}{ Hebron Mud Lake Fen } & \multicolumn{3}{|c|}{ Mullet Creek Fen } \\
\hline & $\begin{array}{r}\text { freq. } \\
\%\end{array}$ & $\begin{array}{l}\% \text { cover } \\
\mathrm{m} \pm \mathrm{s.d} .\end{array}$ & I.V. & $\begin{array}{r}\text { freq. } \\
\%\end{array}$ & $\begin{array}{l}\% \text { cover } \\
\mathrm{m} \pm \mathrm{s} . \mathrm{d} .\end{array}$ & I.V. \\
\hline Andromeda glaucophy/la & 75 & $4 \pm 7$ & 15 & 83 & $9 \pm 10$ & 25 \\
\hline Carex aquatilis & 40 & & 17 & 90 & 0 & 43 \\
\hline C.exilis ${ }^{\mathrm{b}}$ & 38 & - & 5 & & & \\
\hline C. lasiocarpa & 60 & & 26 & 90 & & 43 \\
\hline Cladium mariscoides & 65 & & 29 & & & \\
\hline Drosera rotundifolia & 30 & $2 \pm 6$ & 7 & & & \\
\hline Muhlenbergia glomerata & 35 & $1 \pm 4$ & 5 & 90 & $<1$ & 14 \\
\hline Mirica gale & 93 & $16 \pm 14$ & 34 & 100 & $10 \pm 8$ & 30 \\
\hline Potentilla fruticosa & 25 & $5 \pm 11$ & 9 & & & \\
\hline Salix candida ${ }^{\mathrm{b}}$ & 3 & $<1$ & 0 & 47 & $<1$ & 8 \\
\hline S. pedicellaris ${ }^{\mathrm{b}}$ & 5 & $<1$ & 1 & 33 & $<1$ & 6 \\
\hline Sarracenia purpurea & 38 & $2 \pm 3$ & 8 & & & \\
\hline Thelypteris palustris ${ }^{b}$ & & & & 20 & $1 \pm 4$ & 5 \\
\hline Typha latifolia & 18 & $2 \pm 5$ & 4 & 63 & $1 \pm 1$ & I! \\
\hline Vaccinium subgenus Oxproccos & 43 & $<1$ & 6 & & & \\
\hline Other bryophytes & 90 & $15 \pm 21$ & & 100 & $51 \pm 26$ & \\
\hline Total no. of vascular plants & & 41 & & & 22 & \\
\hline No. of vascular plants with & & & & & & \\
\hline frequency $\geqslant 10 \%$ & & 21 & & & 13 & \\
\hline Total cover of all vascular plants & & 72 & & & 64 & \\
\hline Total cover of all bryophytes & & 15 & & & 51 & \\
\hline
\end{tabular}

a The importance value is the sum of the relative frequency and the relative mean cover.

b Not present at bog and marsh sites studied.

Marsh (c $\leqslant 0.06)$. However, they were moderately similar to Minnehaha Marsh $(\mathrm{c} \cong 0.30)$. This moderate similarity was in agreement with the visual appearance of Minnehaha Marsh, which gave the impression of being a flooded fen. The two marshes had little similarity to each other (c = 0.10). However, Cheboygan Marsh was moderately similar to Hebron 'Swamp' ( $c=0.34$ ) which, in turn, was dissimilar to all other sites.

The total cover of vascular plants and bryophytes at the seven wetland sites also formed a distinct pattern in relation to wetland types (Tables 2, 3, and 4). The bogs and fens had relatively high total vascular cover of between $50 \%$ and $75 \%$, while the marshes and Hebron 'Swamp' had lower cover of between $30 \%$ and $40 \%$. Total bryophyte cover was considerably greater in the bogs and fens than the marshes and Hebron 'Swamp.' Most byrophyte cover in the bogs was due to the 'Sphagnum spp.' group; whereas in the fens and marshes, the cover was entirely due to the 'other bryophytes' group.

\section{Water levels and water characteristics}

Early- to mid-summer water levels within the vegetation at the seven wetland sites are given in Table 6. Mean water levels were well below the surface in the bogs, slightly below the surface at the fens where water was observed at the soil surface at some sample points, and well above the surface in the two marshes and Hebron 'Swamp'.

Physical and chemical characteristics of the standing water sampled for Protozoa in the seven wetlands and Douglas Lake, Michigan, are given in Table 7. The two bog sites show low levels of total alkalinity, conductivity, dissolved oxygen, $\mathrm{pH}, \mathrm{Ca}$, $\mathrm{Mg}$, and $\mathrm{Na}$. Little else in the water chemistry would distinguish wetland sites from Douglas Lake or from most other typical deep, hard-water, unstained, moderately mesotrophic lakes. 
Table 4. Frequency, cover, and importance value (I.V.) of selected plants and other characteristics of the ground layer vegetation of three wetland sites with standing water in northern lower Michigan. All vascular plants with IV $\geqslant 5$ at one of the sites are included.

\begin{tabular}{|c|c|c|c|c|c|c|c|c|c|}
\hline \multirow[t]{2}{*}{ Species } & \multicolumn{3}{|c|}{ Hebron 'Swamp' } & \multicolumn{3}{|c|}{ Cheboygan Marsh } & \multicolumn{3}{|c|}{ Minnehaha Marsh } \\
\hline & $\begin{array}{l}\text { freq. } \\
\%\end{array}$ & $\begin{array}{l}\% \text { cover } \\
\mathrm{m} \pm \mathrm{s} . \mathrm{d} .\end{array}$ & I.V.a & $\begin{array}{l}\text { freq. } \\
\%\end{array}$ & $\begin{array}{l}\text { \%o cover } \\
\mathrm{m} \pm \mathrm{s} . \mathrm{d} .\end{array}$ & l.V. & $\begin{array}{l}\text { freq. } \\
\%_{\%}\end{array}$ & $\begin{array}{l}\% \text { cover } \\
m \pm s . d .\end{array}$ & I.V. \\
\hline Bidens connata ${ }^{\mathrm{b}}$ & 30 & $<1$ & 6 & & & & & & \\
\hline Carex aquatilis & 3 & $1 \pm 6$ & 3 & & & & 63 & $5 \pm 8$ & 29 \\
\hline C. diandara & 33 & $1 \pm 2$ & 8 & & & & 3 & $1 \pm 3$ & 3 \\
\hline C. lasiocarpa & 20 & $<1$ & 4 & & & & 37 & $2 \pm 3$ & 14 \\
\hline C. rostrata & & & & & & & 20 & $1 \pm 3$ & 7 \\
\hline Chamaedaphne calyculata & 60 & $7 \pm 15$ & 32 & & & & & & \\
\hline Cicuta hulbifera & 40 & $<1$ & 7 & & & & 7 & $1 \pm 2$ & 3 \\
\hline Lemna minor & 73 & $8 \pm 16$ & 39 & 63 & $7 \pm 14$ & 35 & 13 & $<1$ & 3 \\
\hline M!rica gale & & & & & & & 47 & $3 \pm 5$ & 18 \\
\hline Myrioph!llum verticillatumc & & & & 30 & $2 \pm 5$ & 12 & 17 & $<1$ & 3 \\
\hline Nuphar variegatumi & & & & & & & 37 & $5 \pm 8$ & 25 \\
\hline Potamageton pusillus & 47 & $<1$ & 8 & & & & & & \\
\hline Potentilla palustris & 60 & $2 \pm 4$ & 17 & & & & 3 & $<1$ & 1 \\
\hline Salix candida & 7 & $2 \pm 9$ & 7 & & & & & & \\
\hline Scirpus acutus & & & & & & & 97 & $10 \pm 10$ & 54 \\
\hline Spirodela polyrhizat & 23 & $<1$ & 4 & 33 & $2 \pm 5$ & 13 & 20 & $<1$ & 4 \\
\hline Thelypteris palustris & 10 & $1 \pm 4$ & 5 & & & & & & \\
\hline Typha latifolia & 60 & $5 \pm 8$ & 27 & 90 & $23 \pm 15$ & 84 & & & \\
\hline Utricularia geminiscapd & 33 & $<1$ & 6 & & & & -23 & $1 \pm 4$ & 9 \\
\hline U. vulgaris & & & & 50 & $2 \pm 2$ & 16 & 33 & $<1$ & 8 \\
\hline Other bryophytes & 37 & $2 \pm 10$ & & 60 & $5 \pm 13$ & & 7 & $<1$ & \\
\hline Total no. of vascular plants & & 30 & & & 25 & & & 26 & \\
\hline \multicolumn{10}{|l|}{ No. of vascular plants with } \\
\hline frequency $\geqslant 10 \%$ & & 19 & & & 9 & & & 13 & \\
\hline \multicolumn{10}{|l|}{ Total cover of all vascular } \\
\hline plants & & 29 & & & 37 & & & 30 & \\
\hline Total cover of all bryophytes & & 2 & & & 5 & & & 1 & \\
\hline
\end{tabular}

${ }^{a} T$ The importance value is the sum of the relative frequency and the relative mean cover.

${ }^{b}$ Present only in Hebron 'Swamp.'

${ }^{\mathrm{c}}$ Not present at bog and fen sites studied.

Table 5. Coefficients of similarity for ground layer vegetation at seven wetland sites in northern lower Michigan șummer, 1977.

\begin{tabular}{|c|c|c|c|c|c|c|c|}
\hline & $\begin{array}{l}\text { Bryant's } \\
\text { Bog }\end{array}$ & $\begin{array}{l}\text { Penny } \\
\text { Lake } \\
\text { Bog }\end{array}$ & $\begin{array}{l}\text { Mud } \\
\text { Lake } \\
\text { Fen }\end{array}$ & $\begin{array}{l}\text { Mullett } \\
\text { Creek } \\
\text { Fen }\end{array}$ & $\begin{array}{l}\text { Cheboy- } \\
\text { gan } \\
\text { Marsh }\end{array}$ & $\begin{array}{l}\text { Minne- } \\
\text { haha } \\
\text { Marsh }\end{array}$ & $\begin{array}{l}\text { Hebron } \\
\text { 'Swamp' }\end{array}$ \\
\hline Bryant's Bog & & 0.46 & 0.05 & 0.01 & 0.00 & 0.01 & 0.17 \\
\hline Penny Lake Bog & 0.46 & & 0.02 & 0.01 & 0.00 & 0.00 & 0.17 \\
\hline Mud Lake Fen & 0.05 & 0.02 & & 0.50 & 0.02 & 0.28 & 0.10 \\
\hline \multicolumn{8}{|l|}{ Mullett Creek } \\
\hline Fen & 0.01 & 0.01 & 0.50 & & 0.06 & 0.33 & 0.17 \\
\hline Cheboygan Marsh & 0.00 & 0.00 & 0.02 & 0.06 & & 0.10 & 0.34 \\
\hline Minnehaha Marsh & 0.01 & 0.01 & 0.28 & 0.33 & 0.10 & & 0.16 \\
\hline Hebron 'Swamp' & 0.17 & 0.17 & 0.10 & 0.17 & 0.34 & 0.16 & \\
\hline Average $\mathrm{c}$ & 0.116 & 0.112 & 0.162 & 0.180 & 0.087 & 0.147 & 0.185 \\
\hline Overall Ave.c $=$ & 0.141 & & & & & & \\
\hline
\end{tabular}


Table 6. Water levels at seven wetland sites in northern lower Michigan. Positive values indicate water standing on the surface and negative values indicate water tables below the surface.

\begin{tabular}{llll}
\hline Site & $\begin{array}{l}\text { Date } \\
\text { sampled }\end{array}$ & $\begin{array}{l}\text { Number of } \\
\text { samples }\end{array}$ & $\begin{array}{l}\text { Depth of water in cm } \\
\mathrm{m} \pm \mathrm{s.d} .\end{array}$ \\
\hline Bryant's Bog & 25 June 77 & 15 & $15.1 \pm 4.3$ \\
& 11 Aug. 77 & 15 & $24.2 \pm 5.1$ \\
Penny Lake Bog & 28 June 77 & 30 & $-43.8 \pm 9.9$ \\
Mullet Creek Fen & 1 July 77 & 30 & $4.7 \pm 3.2$ \\
Hebron Mud Lake Fen & 26 June 77 & 40 & $-6.3 \pm 6.8$ \\
Hebron 'Swamp' & 4 July 77 & 30 & $+38.2 \pm 12.7$ \\
Cheboygan Marsh & 20 July 77 & 30 & $+11.3 \pm 17.9$ \\
Minnehaha Marsh & 14 July 77 & 30 & $+23.5 \pm 9.4$ \\
\hline
\end{tabular}

\section{Protozoan colonization patterns and rates}

Species accumulation or colonization curves for the seven wetlands and for Douglas Lake are presented in Figure 2. At almost all wetland sites, colonization of PFU substrates was extremely rapid. In the bog and fen sites, a substantial percentage of the ultimate number of species accumulating on the PFUs appeared within 1-3 days. Colonization rates for the two marshes and Hebron 'Swamp' were not as rapid. While species numbers were much greater in Hebron 'Swamp,' the overall pattern of species accumulation was very similar to that of Douglas Lake.

Table 8 shows the maximum average number of species (average number recorded from four PFU samples) from each site, the day on which this maximum was reached, and what percent of the maximum number colonized the PFUs by day one. In the two fens, over $90 \%$ of the ultimate maxima was recorded by day one. A very high percentage of the maxima was also recorded on day one PFUs from both bogs and from Cheboygan Marsh. In Hebron 'Swamp', a maximum average of 132.5 species occurred on PFUs collected on day 21 ; in one of these samples, 138 species were identified. The maxima recorded in wetlands other than Hebron 'Swamp' and Mullett Creek Fen were in the same range as the maximum for Douglas Lake.

The MacArthur-Wilson island colonization model adequately described the buildup of species on PFUs at all sites except the two fens (Table 9). Estimates of $G$ (which can be used to compare colonization rates) and Ŝeq (equilibrium species numbers) are presented for sites where there was no significant lack of fit $(\alpha(F)>0.01)$. Substrates from the bog sites had unusually high $G$ values, but $\widehat{S e q}$ numbers that were typical of many lakes (50-60 species). By contrast, PFUs from Hebron 'Swamp,' with the highest Seq we have recorded $(>100$

Table 7. Water chemistry at seven wetland sites and Douglas Lake-summer, 1977.

\begin{tabular}{|c|c|c|c|c|c|c|c|c|c|c|c|}
\hline Site & $\begin{array}{l}\text { Temp. } \\
{ }^{\circ} \mathrm{C}\end{array}$ & $\begin{array}{l}\mathrm{D} . \mathrm{O} . \\
\mathrm{mg} / \mathrm{l}\end{array}$ & $\mathrm{pH}$ & $\begin{array}{l}\text { Cond. } \\
\mathrm{M}\end{array}$ & $\begin{array}{l}\text { Total } \\
\text { alk. } \\
\mathrm{mg} / \mathrm{l}\end{array}$ & $\begin{array}{l}\mathrm{Ca} \\
\mathrm{mg} / \mathrm{l}\end{array}$ & & $\begin{array}{l}\mathrm{Mg} \\
\mathrm{mg} / 1\end{array}$ & $\begin{array}{l}\mathrm{Na} \\
\mathrm{mg} / \mathrm{l}\end{array}$ & $\begin{array}{l}\mathrm{Fe} \\
\mathrm{mg} / \mathrm{l}\end{array}$ & $\begin{array}{l}\mathrm{Zn} \\
\mathrm{mg} / \mathrm{l}\end{array}$ \\
\hline Bryant's Bog & $18.4^{\mathrm{a}}$ & 5.1 & 5.4 & 17.9 & 3.6 & 3.5 & & 1.3 & 0.4 & 0.1 & 0.6 \\
\hline Penny Lake Bog & 18.5 & 7.0 & 5.0 & 35.5 & 2.8 & 2.5 & & 1.0 & 0.9 & 0.2 & 0.2 \\
\hline Mullett Fen & 20.9 & 9.8 & 7.5 & 375.2 & 135.2 & 46.8 & & 15.6 & 3.8 & 0.1 & 0.5 \\
\hline Mud Lake Fen & 20.5 & 10.2 & 7.7 & 339.0 & $111.3 /$ & 40.2 & । & 16.5 & 4.4 & 0.1 & 0.0 \\
\hline Cheboygan Marsh & 21.5 & 9.8 & 8.0 & 324.2 & 149.3 & 62.4 & $\vdots$ & 19.9 & 3.2 & 1.1 & 0.0 \\
\hline Minnehaha Marsh & 22,0 & 9.5 & 7.8 & 343.6 & 137.1 & 52.8 & & 12.4 & 3.0 & 0.1 & 1.2 \\
\hline Hebron 'Swamp' & 20.5 & 7.8 & 7.0 & 187.0 & 161.5 & 24.8 & & 9.1 & 0.3 & 0.1 & 0.1 \\
\hline Douglas Lake & 21.3 & 12.0 & 7.8 & 219.4 & 115.3 & 40.4 & & 12.6 & 3.6 & 0.1 & 1.7 \\
\hline
\end{tabular}

${ }^{a}$ Each value in the table is the mean of five samples. 

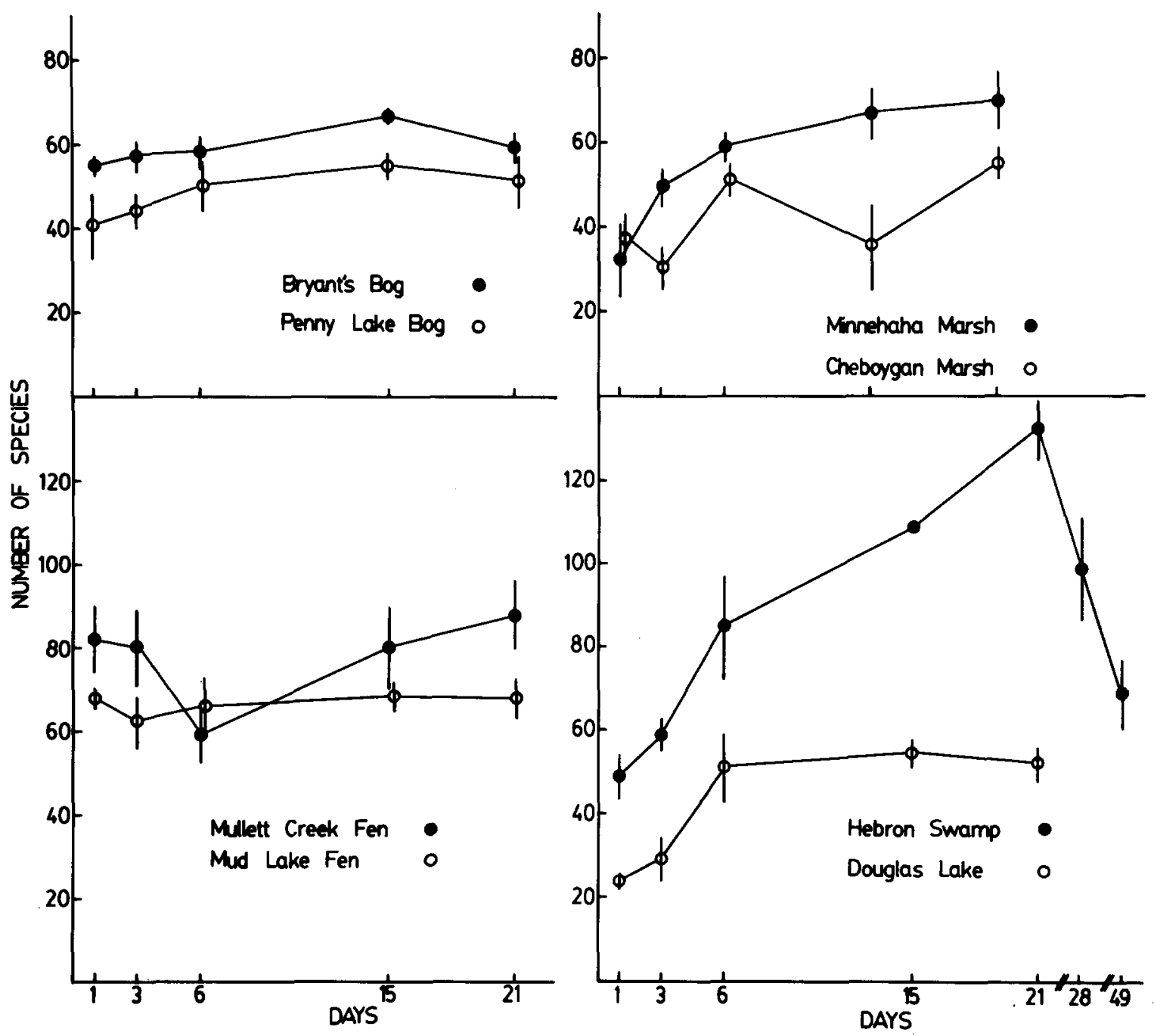

Fig. 2. Protozoan colonization curves for wetlands sampled in summer, 1977. Each point represents the mean number of species on four PFU substrates. The bars represent one standard error of the mean.

species), had a more typical colonization rate. The G value for Hebron 'Swamp' $(0.34)$ was within the range calculated for nearby lakes sampled in 1977 and $1978(0.13-0.91)$.

\section{Results - QS values and flagellate:ciliate:sarcodine ratios}

The overall average similarity of protozoan species content between each pair of sites was 63.4\%; QS values ranged between 54.2 and $75 \%$ (Table 10). Hebron 'Swamp' had the highest average QS with all the other sites $(66.6 \%)$, but was followed closely by Mud Lake Fen (65.6\%), Mullett Creek Fen (64.7\%), and Minnehaha Marsh (64.6\%). Bryant's Bog and Penny Lake Bog, with QS values of $58.3 \%$ and $62.0 \%$, respectively, showed the lowest average similarity to all other sites. Bryant's Bog was most similar to Penny Lake Bog in species composition (QS $=61.2 \%$ ), but Penny Lake was most similar to Mud Lake Fen (QS $=66.2 \%$ ). The two fens, at $71.9 \%$, had the highest species similarity of any two wetlands of the same type. However, the species composition of Mullett Creek Fen was even slightly more similar to that of Hebron 'Swamp' (QS = 73.1\%). Species in Mud 
Table 8. Maximum number of protozoan species, the day on which the maximum was reached, and percent of maximum numbers which colonized PFU substrates by Day 1 in sites sampled in summer, 1977.

\begin{tabular}{lcll}
\hline Site & $\begin{array}{l}\text { Maximum } \\
\text { no. species }\end{array}$ & $\begin{array}{l}\text { Day } \\
\text { maximum } \\
\text { reached }\end{array}$ & $\begin{array}{l}\text { Percent } \\
\text { maximum } \\
\text { by Day 1 }\end{array}$ \\
\hline Penny Lake Bog & $58.8^{\mathrm{a}}$ & 15 & 84.8 \\
Bryant's Bog & 65.2 & 15 & 69.5 \\
Mullett Creek Fen & 88.7 & 21 & 92.7 \\
Mud Lake Fen & 68.5 & 15 & 99.3 \\
Cheboygan Marsh & 55.7 & 21 & 64.4 \\
Minnehaha Marsh & 69.8 & 21 & 44.9 \\
Hebron 'Swamp' & 132.5 & 21 & 33.9 \\
Douglas Lake & 62.0 & 15 & 40.9 \\
\hline
\end{tabular}

Mean number of species on four PFU substrates.

Table 9. Nonlinear regression analysis of model $\mathrm{S}=\hat{\mathrm{Seq}}\left(1-\mathrm{e}^{\mathrm{GT}}\right)$ for colonization of PFU substrates in 11 aquatic systems. Lack of fit (L.O.F.) and $\alpha$ level attained are presented ( $\alpha$ (F) $>0.01$ is required for decision level).

\begin{tabular}{llrlll}
\hline Site & $\begin{array}{l}\text { Year } \\
\text { sampled }\end{array}$ & F & $\alpha(F)$ & $G$ & Seq \\
\hline Bryant's Bog & $(1977)$ & 6.72 & $>0.10$ & $2.42 \pm 0.56$ & $60.26 \pm 1.32$ \\
Penny Lake Bog & $(1977)$ & 2.81 & $>0.25$ & $1.48 \pm 0.38$ & $51.38 \pm 2.07$ \\
Mud Lake Fen & $(1977)$ & 8.93 & $>0.005$ & L.O.F. & L.O.F. \\
Mullett Creek Fen & $(1977)$ & 13.25 & $>0.001$ & L.O.F. & L.O.F. \\
Minnehaha Marsh & $(1977)$ & 2.08 & $>0.10$ & $0.52 \pm 0.07$ & $66.32 \pm 2.42$ \\
Cheboygan Marsh & $(1977)$ & 6.74 & $>0.01$ & $1.64 \pm 0.44$ & $46.25 \pm 4.64$ \\
Hebron 'Swamp' & $(1977)$ & 10.87 & $>0.01$ & $0.34 \pm 0.11$ & $100.16 \pm 7.61$ \\
Douglas Lake & $(1977)$ & 3.33 & $>0.25$ & $0.37 \pm 0.06$ & $53.57 \pm 2.49$ \\
Walloon Lake & $(1978)$ & 1.22 & $>0.25$ & $0.13 \pm 0.03$ & $46.74 \pm 3.58$ \\
Dog Lake & $(1978)$ & 4.32 & $>0.10$ & $0.21 \pm 0.76$ & $37.72 \pm 3.71$ \\
Munroe Lake & $(1978)$ & 1.63 & $>0.25$ & $0.91 \pm 0.86$ & $53.18 \pm 7.07$ \\
\hline
\end{tabular}

Table 10. Quotients of similarity of protozoan species between sites in summer, 1977.

\begin{tabular}{|c|c|c|c|c|c|c|c|c|}
\hline & $\begin{array}{l}\text { Bryant's } \\
\text { Bog }\end{array}$ & $\begin{array}{l}\text { Penny } \\
\text { Lake } \\
\text { Bog }\end{array}$ & $\begin{array}{l}\text { Mud } \\
\text { Lake } \\
\text { Fen }\end{array}$ & $\begin{array}{l}\text { Mullet } \\
\text { Creek } \\
\text { Fen }\end{array}$ & $\begin{array}{l}\text { Cheboy- } \\
\text { gan } \\
\text { Marsh }\end{array}$ & $\begin{array}{l}\text { Minne- } \\
\text { haha } \\
\text { Marsh }\end{array}$ & $\begin{array}{l}\text { Hebron } \\
\text { 'Swamp' }\end{array}$ & $\begin{array}{l}\text { Douglas } \\
\text { Lake }\end{array}$ \\
\hline Bryant's & & 61.2 & 56.7 & 57.0 & 54.2 & 60.4 & 58.0 & 60.6 \\
\hline Penny & 61.2 & & 66.2 & 61.6 & 58.2 & 61.6 & 64.7 & 60.6 \\
\hline Mud & 56.7 & 66.2 & & 71.9 & 61.6 & 65.9 & 70.8 & 66.2 \\
\hline Mullett & 57.0 & 61.6 & 71.9 & & 60.0 & 65.1 & 73.1 & 64.8 \\
\hline Cheboygan & 54.2 & 58.2 & 61.6 & 60.0 & & 66.0 & 75.1 & 60.3 \\
\hline Minnehaha & 60.4 & 61.6 & 65.9 & 65.1 & 66.0 & & 64.3 & 69.2 \\
\hline Hebron & 58.0 & 64.7 & 70.8 & 73.1 & 75.1 & 64.3 & & 60.4 \\
\hline Douglas & 60.6 & 60.6 & 66.2 & 64.8 & 60.3 & 69.2 & 60.4 & \\
\hline $\begin{array}{l}\text { Ave. } Q S= \\
\text { Overall Ave. QS = }\end{array}$ & $\begin{array}{l}58.3 \\
63.4\end{array}$ & 62.0 & 65.6 & 64.7 & 62.2 & 64.6 & 66.6 & 63.1 \\
\hline
\end{tabular}


Table //. Quotients of similarity of abundance = five protozoan species between sites in summer, 1977.

\begin{tabular}{|c|c|c|c|c|c|c|c|c|}
\hline & $\begin{array}{l}\text { Bryant's } \\
\text { Bog }\end{array}$ & $\begin{array}{l}\text { Penny } \\
\text { Lake } \\
\text { Bog }\end{array}$ & $\begin{array}{l}\text { Mud } \\
\text { Lake } \\
\text { Fen }\end{array}$ & $\begin{array}{l}\text { Mullett } \\
\text { Creek } \\
\text { Fen }\end{array}$ & $\begin{array}{l}\text { Cheboy- } \\
\text { gan } \\
\text { Marsh }\end{array}$ & $\begin{array}{l}\text { Minne- } \\
\text { haha } \\
\text { Marsh }\end{array}$ & $\begin{array}{l}\text { Hebron } \\
\text { Swamp }\end{array}$ & $\begin{array}{l}\text { Douglas } \\
\text { Lake }\end{array}$ \\
\hline Bryant's & & 15.0 & 14.8 & 18.2 & 6.4 & 00.0 & 21.0 & 0.00 \\
\hline Penny & 15.0 & & 23.8 & 21.6 & 30.4 & 11.8 & 41.5 & 28.6 \\
\hline Mud & 14.8 & 23.8 & & 40.0 & 23.5 & 36.4 & 29.3 & 8.7 \\
\hline Mullett & 18.2 & 21.6 & 40.0 & & 20.7 & 35.3 & 33.3 & 22.2 \\
\hline Cheboygan & 6.4 & 30.4 & 23.5 & 20.7 & & 00.0 & 26.7 & 14.8 \\
\hline Minnehaha & 00.0 & 11.8 & 36.4 & 35.3 & 00.0 & & 24.2 & 13.3 \\
\hline Hebron & 21.0 & 41.5 & 29.3 & 33.3 & 26.7 & 24.2 & & 23.5 \\
\hline Douglas & 00.0 & 28.6 & 8.7 & 22.2 & 14.8 & 13.3 & 23.5 & \\
\hline Ave. QS & $=10.8$ & 24.7 & 25.2 & 27.3 & 17.5 & 17.3 & 28.5 & 15.9 \\
\hline Overall Ave. QS & $=20.9$ & & & & & & & \\
\hline
\end{tabular}

Lake Fen also showed a high similarity to those of Hebron 'Swamp' (QS $=70.8 \%$ ). The two marshes were neither one as similar to each other in species composition (QS $=66.0 \%$ ) as they were to other sites. Minnehaha Marsh was most similar to Douglas Lake (QS $=69.2 \%$ ) and Cheboygan Marsh was most similar to Hebron 'Swamp'; the QS (75.1\%) for Cheboygan Marsh and Hebron 'Swamp' was the highest recorded.

Table 11 gives the percent similarity of high abundance species between wetland sites; QS values were calculated using only species which exhibited 100 or more individuals per counted subsample (i.e., abundance $=$ five species). Overall average percent species similarity $(\mathrm{QS}=20.9 \%$ ) was much less than when all species were included in the calculations; QS values ranged from $41.5 \%$ between Penny Lake Bog and Hebron 'Swamp' to $0.0 \%$ similarity in three comparisons (Bryant's Bog had no species in common with either Douglas Lake or Minnehaha Marsh, and Minnehaha Marsh and Cheboygan Marsh had no species in common). Hebron 'Swamp' had the highest average QS with all other sites $(28.5 \%)$ species in Bryant's Bog showed the lowest average similarity to other sites (10.8\%).

Table 12 presents total species numbers, numbers of abundance $=$ five species, and flagellate: ciliate:sarcodine ratios found in samples from wetland lakes studied in 1977. An average of 265.9 species were recorded from wetland sites. Hebron 'Swamp' had the greatest species richness (365), followed by Mud Lake Fen at 330 species. Bryant's Bog and Cheboygan Marsh, at 214 and 210 species,

Table 12. Total species recorded from each site, total number of high abundance species, and ratios of flagellates: ciliates: sarcodines.

\begin{tabular}{llllc}
\hline Site & $\begin{array}{l}\text { Total } \\
\text { No. } \\
\text { species }\end{array}$ & $\begin{array}{l}\text { F:C:S } \\
\text { ratio }\end{array}$ & $\begin{array}{l}\text { High } \\
\text { abundance } \\
\text { species }\end{array}$ & $\begin{array}{l}\text { F:C:S } \\
\text { ratio }\end{array}$ \\
\hline Hebron 'Swamp' & 365 & $142: 164: 59$ & 28 & $14: 12: 2$ \\
Mullett Creek Fen & 330 & $120: 151: 59$ & 10 & $4: 5: 1$ \\
Mud Lake Fen & 287 & $109: 125: 53$ & 16 & $5: 9: 2$ \\
Douglas Lake & 248 & $.107: 104: 37$ & 8 & $3: 4: 1$ \\
Penny Lake Bog & 247 & $118: 88: 41$ & 27 & $19: 6: 2$ \\
Minnehaha Marsh & 226 & $85: 106: 35$ & 7 & $4: 3: 0$ \\
Bryant's Bog & 214 & $83: 95: 36$ & 12 & $10: 2: 0$ \\
Cheboygan Marsh & 210 & $82: 90: 38$ & 19 & $13: 15: 1$ \\
Ave. & 265.9 & & 15.9 & \\
\hline
\end{tabular}


respectively, showed the lowest overall species richness. Each site had approximately equal numbers of ciliates and flagellates, with numbers of sarcodine species totalling less than one-fifth of the other two groups. When only the abundance $=$ five species were considered, the bog sites were exceptional in having 3 to 5 times as many flagellates as ciliates; other sites still had approximately $1: 1$ ratios.

\section{Discussion - vegetation}

The vegetation of the three major wetland types examined was distinct with only low levels of similarity between types (Table 5). Moreover, the vegetation of the bogs and fens showed strong within type similarity. In contrast, that of the marshes showed little. These observations are consistent with the nature of the definitions of the three wetland types in the classification (Jeglum et al. 1974) used in this study. The definitions of bog and fen are narrower than that of marsh. They include the behavior of the genus Sphagnum and family Ericaceae, as well as physiognomy of vegetation and groundwater relations.

The vegetation of the bogs and fens is similar to that of other bogs and fens described in northern Michigan and Minnesota. The bogs closely resemble the 'closed mat zone' community type found at each of eight northern Michigan wetland complexes by Vitt \& Slack (1975) and four additional bogs in northern Michigan (Schwintzer, in press). They also show considerable resemblance to the 'Sphagnum-black spruce leatherleaf bog forest' and 'Sphagnum-leather-leaf Kalmia-spruce heath' of northern Minnesota (Heinselman 1970). The fens closely resemble two additional fens in northern Michigan (Schwintzer 1978b) and show considerable resemblance to the 'Cedar-string-bogand-fen' and 'Larch-string-bog-and fen' in northern Minnesota (Heinselman 1970).

The Hebron 'Swamp' site was included in this study because it was the only site with some swamp characteristics available in the unusually dry summer of 1977. However, it lacks one of the major swamp characteristics - the presence of a dominant woody layer consisting of either tall shrubs or trees. Our results show that the site was actually marsh-like as indicated by the pattern of similarities of the vascular vegetation to the other sites studied (Table
5), total vascular and bryophyte cover, and water level (Table 6). The vegetation of Hebron 'Swamp' had a low level of similarity to the bog sites $(c=0.17)$, fen sites $(c=0.10,0.17)$, and Minnehaha Marsh $(c=$ 0.16 ). However, it was moderately similar to Cheboygan Marsh $(c=0.34)$. The similarity between Hebron 'Swamp' and both marshes is greater than that between the two marshes. Thus, Hebron 'Swamp', a highly disturbed site, is probably best considered a marsh at the present time, although it is surrounded by swamp and was occupied by swamp vegetation before it was disturbed.

\section{Discussion of water levels and water chemistry}

The wetlands formed three distinct groups with respect to water levels. Water levels were well below the surface in the bogs, slightly below the surface in the fens, and well above the surface in the marshes and Hebron 'Swamp'. The difference between the bogs and fens on one hand and the marshes on the other is to be expected on the basis of the wetland classification used (Jeglum et al., 1974) and consequent criteria used in site selection. The observed difference between bog and fen sites could not have been anticipated on this basis.

The observed differences in water levels are probably an important factor contributing to the pronounced differences in vegetation in the bogs, fens, and marshes. Water levels are closely related to moisture-aeration regime which is a major environmental influence in wetlands (Heinselman 1963, 1970; Jeglum 1973, 1974; Moore \& Bellamy 1974; Vitt \& Slack 1975; and others) affecting floristics and productivity of vegetation as well as peat development processes. Moisture content of surface peat is rectilinearly correlated with distance between the surface and the water table for water levels ranging from near the surface to $50 \mathrm{~cm}$ beneath the surface (Heikurainen et al. 1964). However, aeration depends on both water level and the extent of water movement (Sparling 1966).

The wetlands formed two distinct groups with respect to chemistry of standing waters. The two bogs had low values for water characteristics reflecting the degree of telluric water influence (water that has percolated through mineral soil or bedrock), namely $\mathrm{pH}$, conductivity, total alkalinity, $\mathrm{Ca}$, and $\mathrm{Mg}$; whereas the remaining five wetlands and Douglas Lake had much higher 
values for these characteristics. Degree of telluric water influence is a major factor in wetland nutrient relations (DuRietz 1954; Sjörs 1950, 1961; Gorham 1967; Heinselman 1970; Moore \& Bellamy 1974; Pietsch 1976; \& others), and two main classes of wetlands are recognized on this basis: (1) ombrotrophic, and (2) minerotrophic. Ombrotrophic wetlands are solely dependent on precipitation for water and minerals. Consequently, their waters are highly deficient in telluric mineral ions and have low $\mathrm{pH}$, conductivity, and total alkalinity. In contrast, at least some telluric water enters minerotrophic wetlands. Here telluric ion content of the water, as well as $\mathrm{pH}$, conductivity, and total alkalinity, depend on the amount of telluric water entering the wetland and the nature of the underlying strata in the region.

The observed values for $\mathrm{pH}, \mathrm{Ca}$, and $\mathrm{Mg}$ in the two bog pools fall within the range of weakly minerotrophic waters (Heinselman 1970; Moore \& Bellamy 1974), indicating that they are largely but not completely isolated from telluric waters by the accumulated organic layers beneath them and the vegetated organic mat surrounding them. In contrast, the waters of the remaining wetlands and Douglas Lake are minerotrophic to strongly minerotrophic(Heinselman 1970; Moore \& Bellamy 1974), indicating strong influence of telluric waters and reflecting the calcareous nature of the bedrock in the region.

The chemistry of the water within the peat where the vegetation is growing can be expected to differ from that in adjacent open pools due to the activities of living plants, decay of dead plant parts, and the buffering effect of peat. Such differences have been observed in Bryant's Bog which has been extensively studied (see Table 1 for references). Welch (1936) noted that the water of the pool was less acid ( $\mathrm{pH}=4.4-6.0)$ than the water impounded in the mat $(\mathrm{pH}=3.4-4.0)$. Later Schwintzer (1978a) observed similar differences in $\mathrm{pH}$ and also

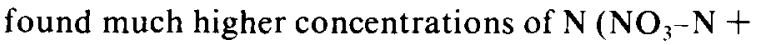
$\mathrm{NH}_{3}-\mathrm{N}$ ) and $\mathrm{P}$ (total-P) in the mat than the pool. These differences are consistent with $\mathrm{H}^{+}$production by the bog vegetation, especially Sphagnum spp. (Hemond, in press), and release of $\mathrm{N}$ and $\mathrm{P}$ by organic matter decay.

\section{Discussion of protozoan colonization patterns and} rates

In studies of over 40 freshwater lakes in Michigan, Colorado, and Virginia which used PFU artificial substrates to collect protozoan species, we have never seen colonization as rapid as at some of the sites in this study. In all other lake studies, 1-3 weeks were required for numbers of protozoan species to reach equilibrium. Colonization in the fens was so rapid $(90 \%$ of ultimate maximum species numbers reached within one day) that the noninteractive colonization model could not be fit to the data. When data from Cheboygan Marsh and the two bog sites were fit to the model, the resulting $G$ values were the highest we have observed.

Cairns et al. (1979) have related the rate at which PFU substrates were colonized by Protozoa to the degree of eutrophication in lake ecosystems. After fitting the noninteractive model to data from their study of Smith Mountain Lake, Virginia, an impoundment of two rivers that has a welldocumented eutrophic gradient, they obtained $G$ values ranging from 0.31 at the cleanest station to 1.43 at the most enriched site. The $G$ values of 2.42 for Bryant's Bog, 1.64 for Cheboygan Marsh, and 1.48 for Penny Lake Bog indicate that these sites were probably more eutrophic than the eutrophic station in Smith Mountain Lake. More evidence of a high degree of eutrophy in bog lakes will be presented in later discussion.

\section{Discussion of QS values}

The percent similarity of protozoan species content between each pair of wetland sites was relatively high, and the QS values for the 28 comparisons in Table 11 fell into a fairly narrow range $(54.2-75.1 \%)$. The average similarity of any one site with all other sites was even narrower $(53.8-66.6 \%)$. This suggests there was probably a 'core' group of species that occurred in bodies of water throughout the study area located in northern lower Michigan. Such a core group of broadly adapted protozoan species was hypothesized in a study of two geographycally proximate but chemically dissimilar bodies of 
water in northern Michigan (Yongue et al. 1973). The overlap of species between those two bodies of water was $>50 \%$, even though they were very dissimilar chemically. Because of the high degree of similarity between sites, differences in QS values using all species provided little evidence that protozoan species pools were unique to certain wetland types. Species in four of the six paired wetland sites were more similar to species pools from another wetland type than to species pools from the same type of wetland. Thus, Penny Lake Bog, Mullett Creek Fen, and Cheboygan Marsh were all more similar to Hebron 'Swamp' than to the other bog, fen, or marsh sites; and Minnehaha Marsh was most similar to Douglas Lake.

Species content in Hebron 'Swamp' may have been highly similar to many other sites partly because it contained so many species (365). An intensive study of Bergen Swamp in the state of New York by Hotchkiss (1950) revealed 345 spècies of algae, and Hohn (1950) recorded 240 species of diatoms for a total count of 585 algal species. Their samples were collected from the swamp over a period of four years, but this still gives some indication of the great number of species of a major taxonomic group which can be found in the diverse swamp habitat. Mullett Creek Fen and Mud Lake Fen also had very high species richness (Table 12), and they likewise had a high similarity of species with many other sites. By contrast, the two sites with the lowest species richness, Bryant's Bog and Cheboygan Marsh, had relatively low similarity to other wetland sites. A site such as Hebron 'Swamp', with a great number of species (richness), would logically have a greater chance for a high number of matches with almost any species pool than would a site with lower species richness. Hebron 'Swamp' may also have a slightly more generalized species pool than the other sites. Similar patterns were found in the vascular vegetation of these same wetland sites. The fen sites had the greatest degree of similarity with each other $(c=0.50)$, followed by the two bog sites $(c=0.46)$. The two marsh sites were not very similar in vegetation, and as in our study of the protozoan species, Cheboygan Marsh was most similar to Hebron 'Swamp'. These results were interpreted as related to the fact that the physical environment at the marsh and 'swamp' sites was quite diverse. Hotchkiss (1950) stressed that the diverse habitats in Bergen Swamp favored the establishment of a great diversity of algal species. By contrast, bog and fen sites are much more narrowly defined physically and chemically. Bog lakes are also harsh environments with low pH's and low total hardness and low cations; these factors have been shown to severely limit the kinds of organisms which can exist in bog lakes (Welch 1936; 1948; Jewel \& Brown 1929).

Percent similarity of high abundance species (abundance $=5$ ) was much less than when all species were included in the calculation of QS values (Table 12). This was shown both in the lower overall similarity of sites with each other (20.9\%), and by the fact that Bryant's Bog had no species in common with two other sites. The two marsh sites had no species in common. This provides strong evidence that the highly abundant species were adapted to, or at least tolerant of, the conditions existing at a particular site. This follows Preston's (1948) assertion, confirmed by Patrick (1967) for diatom communities, that most species in a community exist in relatively low abundance with only a few particularly well adapted species having very high abundances. Hebron 'Swamp' had the highest average QS with all other sites (28.5) when all species were included, while species in Bryant's Bog showed the least average similarity $(10.8 \%)$ to other sites. Again, this may be at least partly a function of the great number of high abundance species in Hebron 'Swamp' ( 28 different species recorded a total of 60 times).

Although different similarity indices were used in the analysis of vascular vegetation and protozoan data, and overall similarity was somewhat different (14.1\% overall for vascular plants vs $58.3 \%$ overall for Protozoa and $20.9 \%$ for abundance $=$ five species), the overall pattern of similarity between sites was comparable. For example, Hebron 'Swamp' had relatively low similarity to bog sites and to Minnehaha Marsh, but had a high similarity to Cheboygan Marsh as measured by both vascular vegetation and protozoan species. For both groups, the greatest similarity between two wetlands of the same type was exhibited by the fen sites. The Pearson product-moment correlation coefficient (Barr et al. 1976) for the average similarity of a particular site with all other sites with respect to vascular vegetation and protozoan species was 0.76 . Thus, a correlation exists between the degree of protozoan community similarity and the vascular plant similarity between sites. 
The percent similarity of protozoan species was calculated for several northern Michigan Lakes sampled in summers of 1977,1978 , and 1979. The highest QS $(62.7 \%)$ was between samples from Walloon Lake and Douglas Lake in 1978; samples from Douglas Lake in 1977, and from Burt Lake in 1978 had the lowest QS (32.4\%). The overall species similarity among lakes sampled in 1978 was $59.2 \%$.

\section{Discussion of flagellate: ciliate: sarcodine ratios}

The ratios of flagellates: ciliates: sarcodines were unlike thoșe reported in previous studies of Protozoa from the bog mat (Heal 1961; Bovee 1979). In those studies where Protozoa were extracted directly from the Sphagnum spp. mat, sarcodines were very important in both numbers of species and in abundance. Bovee (1979) found 33 flagellates, 56 ciliate, and 56 sarcodine Protozoa in a study of an acid Sphagnum bog in the region of Lake Itasca (Minnesota, USA). Heal (1961) studied only testate sarcodines in his investigation of Protozoa in some fens and bogs of northern England. His samples were preserved in $70 \%$ alcohol, which would distort many nontestate species of Protozoa beyond recognition. The live samples from most of our wetland sites had about equal numbers of flagellates and ciliates, with numbers of sarcodine species comprising $<20 \%$ of the total species composition. Among abundance $=$ five species, we found 3 to 5 times as many flagellates as ciliates, with no site having $>2$ species of sarcodines. This disparity in types of species between our study and others can probably be attributed in part to our sampling the open waters rather than the bog mats where conditions seem to favor testate sarcodines (Heal 1961) and in part to our examination of live vs preserved samples. Welch (1936) found only 11 species of Protozoa in net plankton samples from the open water of Bryant's Bog, 5 flagellates, 3 ciliates, and 3 species of sarcodines.

Bricker \& Gannon (1976) have reported very high levels of phytoplankton standing crop, as measured by both chlorophyll - a and direct counts, from several bog lakes in northern lower Michigan. They measured a maximum of $335.5 \mu \mathrm{g} / 1$ chlorophyll - a and mean surface value of $54.8 \mu \mathrm{g} / 1$ chlorophyll from Hoop Lake bog in 1975. Their studies included Bryant's Bog. Schwintzer (1978b) noted that Bryant's and Hoop Lake bogs are similar with respect to many physical and chemical parameters.

As Bricker \& Gannon (1976) point out, recent trophic classification schemes consider lakes with chlorophyll - a values over $10-15 \mu \mathrm{g} / \mathrm{l}$ as eutrophic (Sakamoto 1966; National Academy of Sciences 1972; USEPA 1974). Therefore, Hoop Lake and Bryant's Bog lakes could be considered eutrophic, or even hypereutrophic, based on standing crop of phytoplankton. Of the four major wetland types, acid bogs have been found to have the lowest net primary production of macrophyte vegetation (Richardson 1979). Acid bog lakes are generally considered faunistically depauperate and often lack fishes and many invertebrate groups (Barry \& Schlinger 1977 as cited in Clark 1979). Earlier investigators considered these and other northern lower Michigan bogs low in plankton productivity and decidedly dystrophic (Jewel \& Brown 1929; Gorham 1931; Welch 1936). However, they looked primarily at net phytoplankters. Bricker \& Gannon (1976) found that the nannophytoplankters Chlorella and Dictyosphaerium were two of the predominant algal species in their study of Hoop Lake Bog. They concluded that since Dictyosphaerium pulchellum was consistently found below the level of light penetration during summer, and since pigmented algae have been observed to utilize dissolved organic substances for energy and growth (Samejima \& Meyers 1958; Parker et al. 1961; Danforth 1962; Stanier 1973), that it was possible that both heterotrophy and photosynthesis may have been responsible for the algal blooms under low light conditions in Hoop Lake.

Our studies of Protozoa (including the phytoflagellate algae) dealt with a portion of the nannoplankton which to our knowledge has never been systematically studied in wetland lakes. Because of their open-cell structure, PFU artificial substrates collect many planktonic Protozoa as well as substrate-associated sessile and crawling forms (Henebry \& Cairns 1980). (For scanning electron micrographs of the structure of PFU substrates and some of the early colonizers of these units, see Paul et al. 1977). The nannoplankton seen in Bricker \& Gannon's study, because it was from preserved samples, consisted of either nonmotile groups with rigid cell walls (Clorophyceae), motile algae with loricas (Chrysophyceae, Bacillarieae), or 
Table 13. Abundance $=5^{\mathrm{a}}$ species of Protozoa from seven wetland sites sampled in summer, 1977.

Wetland sites

\begin{tabular}{|c|c|c|c|c|c|c|}
\hline $\begin{array}{l}\text { Bryant's } \\
\text { Bog }\end{array}$ & $\begin{array}{l}\text { Penny } \\
\text { Lake } \\
\text { Bog }\end{array}$ & $\begin{array}{l}\text { Mud } \\
\text { Lake } \\
\text { Fen }\end{array}$ & $\begin{array}{l}\text { Mullett } \\
\text { Creek } \\
\text { Fen }\end{array}$ & $\begin{array}{l}\text { Cheboy- } \\
\text { gan } \\
\text { Marsh }\end{array}$ & $\begin{array}{l}\text { Minne- } \\
\text { haha } \\
\text { Marsh }\end{array}$ & $\begin{array}{l}\text { Hebron } \\
\text { 'Swamp' }\end{array}$ \\
\hline
\end{tabular}

Mastigophora [35]

Glenodinum edax (17)

Anthophysis vegetans (13)

Chroomonas caudata (11)

Gonyostomum semen (10)

Crathomonas truncata (8)

Dereplixis sp. (6)

Chlamidomonas sp. (5)

Chroomonas nordstedii (5)

Colacium sp. (5)

Cryptomonas erosa (5)

C. ovata (5)

Euglena convoluta (5)

Chromulina globosa (4)

Massartia musei (4)

Pleuromonas jaculans (4)

Dinobrion divergens (3)

Gimnodinium fuscum (3)

Chilomonas paramecium (2)

Chrisocapsa sp. (2)

Crypromonas lucens (2)

Ochromonas sp. (2)

Fen

Phacus obicularis (2)

Chromulina pascheri (1)

Chroomonas curvicauda (1)

Cryptomonas plat!uris (1)

Entosiphon obliquum (1)

Euglena hemichromata (1)

E. rubra (1)

$\begin{array}{ll}16^{\mathrm{b}} & 1 \\ & 1 \\ & 5 \\ 1 & 2 \\ & 1\end{array}$

2

2

2

5

5

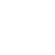

3

2

1

1

1

Gonvostomum notail (1)

Halobryon sp. (1)

Merotricha bacillata (1)

Monas sp. (1)

Monas social (1)

Monosiga robusta (1)

Phacus pleuronectes (1)

Sarcodina [5]

Cochliopodium sp. (6)

Acanthocystis aculeata (2)

Arcella vulgaris (1)

Difflugia globosa (1)

Vampyrella sp. (1)

Ciliata [24]

Urotricha agilis (11)

Cinetochilum margaritaceum (7)

Halteria grandinella (4)

Urotricha armata (4)

\section{I}

3

l

3 
Table 13 (cont.')

\begin{tabular}{|c|c|c|c|c|c|c|c|}
\hline & & & & Wetland & & & \\
\hline & $\begin{array}{l}\text { Bryant's } \\
\text { Bog }\end{array}$ & $\begin{array}{l}\text { Penny } \\
\text { Lake } \\
\text { Bog }\end{array}$ & $\begin{array}{l}\text { Mud } \\
\text { Lake } \\
\text { Fen }\end{array}$ & $\begin{array}{l}\text { Mullett } \\
\text { Creek } \\
\text { Fen }\end{array}$ & $\begin{array}{l}\text { Cheboy- } \\
\text { gan } \\
\text { Marsh }\end{array}$ & $\begin{array}{l}\text { Minne- } \\
\text { haha } \\
\text { Marsh }\end{array}$ & $\begin{array}{l}\text { Hebron } \\
\text { 'Swamp' }\end{array}$ \\
\hline Coleps bicuspis (2) & & & & & 1 & & 1 \\
\hline CI'clidium glaucoma (2) & & & 1 & & 1 & & \\
\hline C. litomesum (2) & & & & & & & 2 \\
\hline Cyrtolophosis mucicola (2) & & 1 & & & & & 1 \\
\hline Mesodinium pulex (2) & & & & & 2 & & \\
\hline Microthorax ridentatus (2) & & 1 & & & & & 1 \\
\hline Ophrydium ectatum (2) & & 2 & & & & & \\
\hline O. vernalis (2) & & & $\mathbf{I}$ & & & & 1 \\
\hline Pleuronema crassum (2) & & & & & & & 2 \\
\hline Urotricha farcta (2) & & & & 2 & & & \\
\hline Balanonema biceps (1) & & & & & & & 1 \\
\hline Ballad!na sp. (1) & & & & & & 1 & \\
\hline Coleps hirlus (1) & & & & & 1 & & \\
\hline Euplotes patella (1) & & & & & & & 1 \\
\hline Lembadion bullinum (1) & & 1 & & & & & \\
\hline Microthorax spiniger (1) & & & 1 & & & & \\
\hline Ophrydium versatile (1) & & & 1 & & & & \\
\hline Stentor polymorphus (1) & & 1 & & & & & \\
\hline Stylonichia mytilis (1) & & & & & & & 1 \\
\hline Tetrahymena vorax (1) & 1 & & & & & & \\
\hline Total \# Species (64) & 12 & 27 & 16 & 10 & 19 & 7 & 28 \\
\hline $\begin{array}{l}\text { Total \# times } A B N=5(200) \\
\text { F:C:S ratio }=35: 24: 5\end{array}$ & 31 & 43 & 23 & 13 & 22 & 10 & 60 \\
\hline
\end{tabular}

${ }^{\mathrm{a}} 100+$ individuals per slide.

${ }^{b}$ Number of samples in which a species was highly abundant.

blue-green algae (Myxophyceae). Our samples were examined live and contained many species of Protozoa and motile algae. Most of these organisms are destroyed or distorted beyond recognition by preservation techniques. We also observed Dictyosphaerium, Chlorella, desmids, diatoms, and blue-green algae, but the protozoan component was represented in large numbers and was much more diverse. Table 13 lists only the highly abundant species found in wetland sites, yet 12 and 27 of these species were found in Bryant's Bog and Penny Lake Bog, respectively. Bricker \& Gannon (1976) found only 23 total species of nannophytoplankton in the pool of Hoop Lake Bog. This disparity in numbers of species was even greater when considering the total species richness in our samples. There were 83 species of flagellates in the pool of Bryant's Bog, and 118 species in Penny Lake Bog; most of these were what phycologists would consider motile green algae. When all Protozoa in our samples are included (flagellates, ciliates, and sarcodines), total numbers of species rise to 214 for Bryant's Bog and 247 for Penny Lake Bog. These numbers are within the range for other lakes and wetlands in northern lower Michigan and certainly do not indicate a restricted pool of Protozoan species in bog sites.

An unusually high number of protozoan species in our samples seemed to be utilizing photosynthesis in their metabolism; most samples were green and turbid from the high numbers of chlorophyl-bearing organisms. Not only were such phytoflagellates as Glenodinium, Croomonas, Cryptomonas, Gonyostomum, and Chlamydomo- 
nas found in large numbers, but many abundant ciliates contained what appeared to be zoochlorellae. Those ciliates included Ophrydium ectatum and Stentor polymorphous; Paramecium burasaria was also found in lower abundance in both bogs. Zoochlorellae are typically found in the above species (Kahl 1930-1935; Kudo 1966). Nearly the whole surface of the shallow flocculent bottom of the pool of Penny Lake. Bog was covered with a bloom of 'Ophyrydium balls', composed of Ophrydium ectatum. Thus, a very significant amount of photosynthetic activity may have been undertaken by the large protozoan component of the microbial communities of bog pools in our study.

\section{Summary and conclusions}

In respect to both vascular vegetation and species composition of protozoan communities, clear differences emerge between bogs, fens, and marshes. This is particularly interesting in the case of the protozoan communities since most protozoan species are able to tolerate a broad range of physical and chemical conditions (Cairns 1964; Noland \& Gojdics 1967).

1. The wetlands examined formed three distinct groups with respect to vascular vegetation and midsummer water levels. The vegetation differed strongly between bogs, fens, and marshes and was very similar within the bogs and fens but differed within the marshes. Midsummer water levels were well below the surface in the bogs, near the surface in the fens, and well above the surface in the marshes. The highly disturbed Hebron 'Swamp' site was marshlike in vegetation and water level and is probably best considered a marsh.

2. The wetlands formed two distinct groups with respect to chemistry of the standing waters: bogs, and all other sites including Douglas Lake. The bogs were weakly minerotrophic, and all the other sites were minerotrophic to strongly minerotrophic.

3. The similarities and differences between wetland sites were not as great for Protozoa as for vascular vegetation, but the patterns were similar. Between two wetlands of the same type, fens were the most similar in respect to both vascular vegetation and protozoan communities; bogs were the next most similar to each other for both groups.
In marsh sites, there was less similarity between both vascular vegetation and protozoan communities. Hebron 'Swamp' was highly similar to Cheboygan Marsh with respect to both vascular vegetation and protozoan communities.

Similarities between sites were much higher when all species of Protozoa were considered than when only the high abundance species were used to calculate a quotient of similarity. These findings were consisitent with the hypothesis that many species of microorganisms (including Protozoa) can exist under a wide variety of conditions, but particular species become abundant only when conditions are favorable.

4. The standing water in bog sites was the most distinct chemically, and protozoan community composition in bogs was likewise most distinct from other types of wetlands. The species richness in bogs was lower than the average for all wetland sites. Among the abundance $=5$ species, bogs had very high flagellate:ciliate ratios -3 to 5 times as many flagellates as ciliates vs approximately a $1: 1$ ratio in other types of wetlands. Also, a very high proportion of Protozoa in bogs contained chlorophyll in either chloroplasts in flagellates or in what appeared to be zoochlorellae in ciliates. Whether or not these chlorophyll - containing Protozoa were actively carrying on photosynthesis is not clear.

5. The colonization rate of the PFU artificial substrates by Protozoa at fen and bog sites and Cheboygan Marsh was the highest we have measured in studies of over 40 lakes representing all trophic levels. This indicates that the open waters at these wetland sites may have been highly eutrophic. Marshes characteristically show the highest total productivity of all wetland systems (National Wetlands Technical Council 1979); however, these findings seem to contradict the general concept that bog lakes are dystrophic.

6 . There have been few studies of the open waters of wetlands and no comprehensive simultaneous sampling of Protozoa and vascular vegetation in several major types of wetlands. As such, our study was the first of its kind. We found wetland sites to have generally greater numbers of protozoan species than lake sites in the same region of northern lower Michigan. Substrates from Hebron 'Swamp' (at 365 species) and Mullett Creek Fen (at 330 species) contained the greatest number of 
protozoan species reported from any body of freshwater that we have examined (species lists from each site would be far too lengthy to be included in this paper but are stored in the I.B.M. 370 computer at VPI \& SU). We have presented the highly abundant species from each site in Table 13.

It would have been virtually impossible to collect Protozoa directly from each of the microhabitats in the wetland sites even if sufficient time had been available. We feel that the use of artificial substrates was the only practical method of sampling Protozoa of these wetland sites. The PFUs probably did not collect Protozoa from all possible microhabitats at each site nor could they possibly have collected a representative of every species at each site. But PFUs do provide a uniform substrate for colonization by Protozoa and, as the error bars in Fig. 1 show, the number of species collected by PFUs was generally highly replicable. Also, there is evidence that PFUs do collect a community that is quite similar to that sampled from natural substrates (Cairns et al. 1974).

In conclusion, the structure and dynamics of protozoan communities of wetlands seem to be broadly different from that of other freshwaters, and somewhat unique to particular wetland types. However, protozoan communities of wetlands do also appear to be part of a continuum of those found in other freshwaters that we have examined since they contain many species also found regularly in these other systems.

\section{Acknowledgments}

We thank everyone at The University of Michigan Biological Station who has aided in this study. Margie Ladzick and Michael van Brundt helped collect Protozoa and water chemistry data. Special thanks are due to June M. Dobberpuhl for extensive help with data collection in the field and data compilation, and Edward G. Voss and Robert R. Haynes for help with plant identification. The work on wetland plants was supported in part by The University of Michigan Biological Station. The main support was provided by Energy Research and Development Administration contract (E-(40-1)-4939).

\section{References}

Alfred, S. D., A. G. Hyde \& Larson. R. L., 1973. Soil survey of Emmet County, Michigan. US Dept. of Agriculture and Soil Conservation Service. Maps $1-45$.

Bailey, R. G., 1976. Ecoregions of the United States. Map. US Forest Service, Ogden, Utah.

Barr, A. J., J. H. Goodnight, J. P. Sall \& Helwig, J. T., 1976. A User's Guide to S.A.S., Raleigh, North Carolina: S.A.S. Institute.

Bevis, F. B., 1960. Phytosociological study of lnverness Mud Lake Bog, Cheboygan County. Pap. Mich. Acad. Sci. Arts Lett. 45: $61-75$.

Bovee. E. C.. 1979. Protozoa from acid-bog mosses and forest mosses of the Lake Itasca Region (Minnesota, USA) Univ. Kans. Sci. Bull. 51: 615-629.

Bricker, F. J.\& Gannon. J. E., 1976. Limnological investigation of Hoop Lake - a northern Michigan Bog. Mich. Acad.: 2542.

Cairns, J., Jr., 1964. The chemical environment of common fresh water protozoa. Not. Nat. 365: 1-6.

Cairns, J., Jr., D. L. Kuhn \& Plafkin, J. L., 1979. Protozoan colonization on artificial substrates. In: Methods and Measurements of Periphyton. Communities: A Review, Ed.. R. L. Weitzel, Philadelphia. Pa. American Society for Testing and Materials: pp. 3456.

Cairns, J., Jr. \& Yongue, W. H., 1974. Protozoan colonization rates on artificial substrates suspended at different depths. Trans. Am. Micros. Soc. 93: 206-210.

Cairns, J., Jr., W. H. Yongue, Jr. \& Boatin, Jr. H., 1973. The protozoan colonization of polyurethane foam units anchored in the benthic area of Douglas Lake, Michigan. Trans. Am. Micros. Soc. 92(4): 648 656.

Cairns, J., Jr., W. H. Yongue, Jr. \& Smith. N.. 1974. The effects of substrate quality upon colonization by freshwater protozoan communities. Revis. Biol. 10: 13-20.

Clark, J. E., 1979. Freshwater wetlands: habitats for aquatic invertebrates, amphibians, and fish. In: Wetland Functions and Values: The State of Our Understanding, Eds. P. E. Greeson. J. R. Clark, and J. E. Clark, American Water Resources Association, pp. 330 342.

Cox, G, W.. 1972. Laboratory Manual of General Ecology, 2nd ed. Dubuque, lowa. Wm. C. Brown Co.: 195 pp.

Curtis, J. T., 1959. The Vegetation of Wisconsin. Madison: Univ. of Wisconsin Press

Danforth, W. F., 1962. Substrate assimilation and heterotrophy. In: Physiology and Biochemistry of Algae, Ed. R. A. Levin. N.Y. Acadernic Press.: pp. 99-123.

Dorr, J. A., Jr. \& Eschman, D. F., 1970. Geology of Michigan. Ann Arbor: Univ. of Michigan Press.

DuRietz, E. G., 1954. Die Mineralboden-wasserzeigergrenze als Grundlage einer natürlichen Zweigliederung der Nord - und Mitteleuropäischen Moore. Vegettatio 5/6: 571-585.

Fernald, M. L., 1950. Gray's Manual of Botany, 8th ed. New York. American Book Co.: $1632 \mathrm{pp}$.

Gannon, J. E. \& Paddock, M. W., 1974. Investigations into ecological and sociological determinants of land - use decision a study of inland lake watersheds in northern Michigan. Univ. of Michigan Biological Station Tech. Rept. No. 1: $314 \mathrm{pp}$. 
Gates, F. C., 1942. The bogs of Northern Lower Michigan. Ecol. Monogr. 12: 213-254.

Gorham, E., 1967. Some chemical aspects of wetland ecology. Pages 20-38. In: 12th Ann. Muskeg Res. Conf. Proc., Technical Memorandum 90, National Research Council Associated Committee on Geotechnical Research, Canada.

Gorham, W. C, 1931. A limnological study of certain bog lakes with special reference to the macroplankton. Unpubl. Ph. D. Diss., Univ. of Michigan. $126 \mathrm{pp}$.

Heal, O. W., 1961. The distribution of testate amoebae (Rhizopoda: Testacea) in some fens and bogs in northern England. J. Linn. Soc. London, Zool. 64: 369-382.

Heikurainen, L., J. Paivanen \& Sarasto J., 1964. Ground-water table and water content in peat soil. Acta. For. Fenn. 77(1): $1-18$.

Heinselman, M. L., 1963. Forest sites, bog processes, and peatland types in the Glacial Lake Agassiz Region, Minnesota. Ecol. Monogr. 33: 327-374.

Heinselman, M. L., 1970. Landscape evolution, peatland types, and the environment of the Lake Agassiz Peatlands Natural Area, Minnesota. Ecol. Monogr. 40: 235-26l.

Hemond, H. F. In press. Biogeochemistry of Thoreau's Bog, Concord, Massachusetts. Ecol. Monogr.

Henebry, M. S. \& Cairns, Jr. J., 1980. The effect of source pool maturity on the process of island colonization: an experimental approach with protozoan communities. Oikos 35 : 107-114.

Hohn, M. H., 1950. The vegetation of Bergen Swamp, V: The Diatoms (Bacillarieae). Proc. Rochester Acad. Sci. 9: 265-275.

Holcombe, J. W., 1976. The bryophyte flora of Thuja seedbed logs in a northern white-cedar swamp. Mich. Bot. 15: 173-181.

Hotchkiss, A. T., 1950. The vegetation of Bergen Swamp, IV: The Algae. Proc. Rochester Acad. Sci. 9: 237-264.

Jahn, T. L. \& Jahn, F. F., 1949. How to Know the Protozoa. Dubuque, lowa: Wm. C. Brown Co., 234 pp.

Jeglum, J. K., 1973. Boreal forest wetlands, near Candle Lake, central Saskatchewan, Part II: Relationships of vegetational variation to major environmental gradients. Musk. Ox. 12: $32-48$.

Jeglum, J. K., 1974. Relative influence of moisture-aeration and nutrients on vegetation and black spruce growth in northern Ontario. Can. J. For. Res. 4: 114-126.

Jeglum, J. K., A. N. Boissonneau \& Haavisto, V. F., 1974. Towards a wetland classification for Ontario. Canadian Forestry Service Department of the Environment. Information Report O-X-215.

Jewel, M. E. \& Brown, W. H., 1929. Studies on northern Michigan bog lakes. Ecology 10: 427-475.

Johns, R. M., 1966. Morphological and ecological study of Physoderma dulichii. Am. J. Bot. 58: 34-45.

Kadlec, J. A., 1961. A further comment on the ecology of woolgrass (Scirpus cyperinus). Ecology 42: 591-592.

Kahl, A., 1930-1935. Urtiere oder Protozoa. I: Wimpertiere oder Ciliata (Infusoria), eine Bearbeitung der feilebenden und Ecotcommensalen Infusorien der Erde, unter Ausschluss der Marinen Tintinnidae. In: Die Tierwelt Deutschlands, Ed., Dahl, F., parts 18 (year 1930), 21 (1931), 25 (1932), 30 (1935), Jena: G. Fischer: pp.1-886.
Kudo, R. R., 1966. Protozoology, 5th ed. Springfield, Illinois: Charles C. Thomas, 1174 pp.

Michigan Department of Agriculture, Michigan Weather Service. 1971. Climate of Michigan by Stations, 2 nd ed. East Lansing, Michigan (Loose leaf. n.p.).

Moore, P. D. \& Bellamy, D. J., 1974. Peatlands. New York: Springer-Verlag, 221 pp.

National Academy of Sciences, 1972. Water Quality Criteria of 1972. Washington, D.C

National Wetlands Technical Council, 1979. National symposium on wetland values report to federal agency. Review Draft: $127 \mathrm{pp}$.

Noland, L. E. \& Gojdics, M., 1967. Ecology of free-living protozoa. In: Research in Protozoology, Vol. 2, Ed., Chen, T. T., London and New York: Pergamon Press: pp. 215-266.

Odum, E. P., 1971. Fundamentals of Ecology, 3rd ed. Philadelphia: W. B. Saunders Co., 574 pp.

Parker, B. C., H. C. Bold \& Deason, T. R., 1961. Facultative heterotrophy in some chlorococcacean algae. Science 133 : $781-763$.

Pascher, A., 1913-1927. Flagellates. In Die Susswasser-flora Deutschlands, Osterreich und der Schweiz. Jena: G. Lischer.

Patrick, R. 1967. The effect of invasion rate, species pool, and size of area on the structure of the diatom community. Proc. Acad. Nat. Sci. 58: 1335-1342.

Paul, R. W., D. L. Kuhn, J. L. Plafkin, J. Cairns, Jr. \& J. G. Croxdale. 1977. Evaluation of natural and artificial substrate colonization by scanning electron microscopy. Trans. Am. Micros. Soc. 96: 506-519.

Pietsch, W., 1976. Vegetationsentwicklung und wasserchemische Faktoren in Mooregewässern verschiedener Naturschutzgebiete der DDR. Arch. Naturschutz Landschaftsforsch. 16: 1-43.

Plafkin, J. L., D. L. Kuhn, J. Cairns, Jr. \& Yongue, Jr. W. H. In press. Protozoan species accrual on artificial islands in differing lentic and wetland systems. Hydrobiologia.

Preston, F. W., 1948. The commoness and variety of species. Ecology 29: 254-283.

Richardson, C. J., 1979. Primary productivity values in fresh water wetlands. In: Wetland Functions and Values: The State of Our Understanding, Eds. P. E. Greeson, J. R. Clark, and J. E. Clark, American Water Resources Association, pp. $131-145$

Sakamoto, M., 1966. Primary production by phytoplankton community in some Japanese lakes and its dependence on lake depth. Arch. Hydrobiol. 62: 1-28.

Samejima, H. \& Meyers, J., 1958. On the heterotrophic growth of Chlorella pyrenoidosa. J. Gen. Microbiol. 18: 107-117.

Schwintzer, C. R., 1978a. Nutrient and water levels in a small Michigan bog with high tree mortality. Am. Midl. Nat. 100: $441-451$.

Schwintzer, C. R., 1978b. Vegetation and nutrient status of northern Michigan fens. Can. J. Bot. 56: 3044-3051.

Schwintzer, C. R., 1979. Vegetation changes following a water level rise and tree mortality in a Michigan Bog. Mich. Bot. 18: $91-98$.

Schwintzer, C. R. In press. Vegetation and nutrient status of northern Michigan bogs and conifer swamps with a comparison to fens. Can. J. Bot. 
Schwintzer, C. R. \& Williams, G., 1974. Vegetation changes in a small Michigan bog from 1917 to 1972. Am. Midl. Nat. 92: 447-459.

Sjörs, H., 1950. On the relation between vegetation and electrolytes in north Swedish mire waters. Oikos 2: 241-258.

Sjörs, H., 1961. Forest and peatland at Hawley Lake, Northern Ontario. Natl. Mus. Can. Bull., Contrib. to Botany 171: $1-31$.

Smith, G. M., 1950. The Freshwater Algae of the United States, 2nd ed. N.Y., McGraw-Hill: 719 pp.

Sorensen, T., 1948. A method of establishing groups of equal amplitude in plant sociology based on similarity of species content. K. Dan. Vidensk. Selsk. Biol. Skr. 5: 1 - 34.

Sparling, J. H., 1966. Studies on the relationship between water movement and water chemistry in mires. Can. J. Bot. 44: 747-758

Spurr, S. H. \& Zumbarge, J. H., 1956. Late Pleistocene features of Cheboygan and Emmet Counties. Michigan. Am. J. Sci. 254: 96-109.

Stanek, W. \& Jeglum, J. K. Appendix by L. Orloci. 1977. Comparisons of peatland types using macro-nutrient contents of peat. Vegetatio 33: 163-173.

Stanier, R. Y., 1973. Autotrophy and heterotrophy in unicellular blue-green algae. In: The Biology of the Blue Green Algae, B. A. Whitton, Berkeley: Univ. of California Press: pp. 501-518

US Dept. of Commerce, NOAA; National Ocean Survey. 1971. Great Lakes Water Levels: 1860-1970.

US Dept. of Interior, Geological Survey. Water Resources Data for Michigan, Part I: Surface Water Records. Published yearly 1961-1976.
US Environmental Protection Agency, 1974. The relationship of phosphorous and nitrogen to the trophic state of northeast and north-central lakes and reservoirs. National Eutrophication Survey, Corvallis, Oregon. Working Paper, No. 23, 28 pp.

Vitt, D. H., H. Crum \& Snider, J., 1975. The vertical zonation of Sphagnum species in hummock-hollow complexes in northern Michigan. Mich. Bot. 14: 190-200.

Vitt, D. H. \& Slack, N. G., 1975. An analysis of the vegetation of Sphagnum-dominated kettle-hole bogs in relation to environmental gradients. Can J. Bot. 53: 332-359.

Voss, E. G., 1972. Michigan Flora, Part 1: Gymnosperms and Monocots. Bloomfield Hills, Michigan: Cranbook Institute of Science, $488 \mathrm{pp}$.

Webb, T., 1974. Corresponding patterns of pollen and vegetation in lower Michigan: a comparison of quantitative data. Ecology 55: 17-28.

Welch, P. S., 1936. A limnological study of small sphagnumleather-leaf black spruce bog lake with special reference to its plankton. Trans. Am. Micros. Soc. 55: 300-322.

Welch, P. S., 1948. Limnology. New York: McGraw-Hill.

Wetzel, R. G., 1975. Limnology. Philadelphia: W. B. Saunders, $743 \mathrm{pp}$.

Yongue, W. H., Jr., J. Cairns, Jr. \& Boatin, H., Jr., 1973. A comparison of freshwater protozoan communities in geographically proximate but chemically dissimilar bodies of water. Arch. Protistenk. 115: 154-161.

Received October 27, 1980. 